\title{
(Section 113)
}

\section{Progress Report on the Scientific Investigation Program for the Nevada Yucca Mountain Site}

September 15, 1988 - April 15, 1989

April 16, 1989 - September 30, 1989

Number 1

February 1990

U.S. Department of Energy

Office of Civilian Radioactive Waste Management

Washington, DC 20585 



\section{DISCLAIMER}

This report was prepared as an account of work sponsored by an agency of the United States Government. Neither the United States Government nor any agency thereof, nor any of their employees, make any warranty, express or implied, or assumes any legal liability or responsibility for the accuracy, completeness, or usefulness of any information, apparatus, product, or process disclosed, or represents that its use would not infringe privately owned rights. Reference herein to any specific commercial product, process, or service by trade name, trademark, manufacturer, or otherwise does not necessarily constitute or imply its endorsement, recommendation, or favoring by the United States Government or any agency thereof. The views and opinions of authors expressed herein do not necessarily state or reflect those of the United States Government or any agency thereof. 


\section{DISCLAIMER}

Portions of this document may be illegible in electronic image products. Images are produced from the best available original document. 


\section{FOREWORD}

In accordance with the requirements of Section 113(b)(3) of the Nuclear Waste Policy Act of 1982 (Pub. L. No. 97-425), as amended, the Department of Energy (DOE) has prepared this report on the progress of site characterization activities at Yucca Mountain in southern Nevada. This report is the first of a series of reports that will hereafter be issued at intervals of approximately 6-month during site characterization.

The DOE had planned to issue the first progress report, covering the period of September 15, 1988, through April 15, 1989, in July 1989. However, as a result of an ongoing review of the Civilian Radioactive Waste Management Program by the Secretary of Energy, issuance of the first progress report was delayed. The Secretary's review of the program has been completed, and a report titled Report to Congress on Reassessment of the Civilian Radioactive Waste Management Program was provided to Congress on November 29, 1989. The Secretary's report outlines the actions that must be taken in order to proceed with new site characterization activities at the Yucca Mountain site.

With the release of the Secretary's report, the DOE is now issuing the first (September 15, 1988, through April 15, 1989) and the second (April 16, 1989, through September 30,1989 ) progress reports as a combined progress report on site characterization activities at Yucca Mountain. Because the reporting period ended 2 months before the issuance of the Secretary's report, the combined progress report, with the exception of Section 3, "Schedules," does not reflect all the changes to the site characterization program resulting from the Secretary's review of the program. Such changes will be addressed in future progress reports. However, Section 3 of the report does provide the repository program schedule baseline that was discussed in the Secretary's report. 


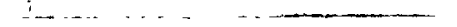




\section{TABLE OF CONTENTS}

EXECUTIVE SUMMARY $\ldots \ldots \ldots \ldots \ldots \ldots \ldots \ldots \ldots$

1. INTRODUCTION $\ldots \ldots \ldots \ldots \ldots \ldots \ldots \ldots \ldots \ldots \ldots \ldots$

1.1 Purpose and Scope of the Progress Report $\ldots \ldots \ldots \ldots \ldots \ldots \ldots \ldots$

1.2 Background Information . . . . . . . . . . . . . . . . 3

1.2.1 Site Characterization .................. 4

1.2.2 The Site Characterization Plan . ................ 5

1.2.3 Participation by the State of Nevada and

Affected Units of Local Government ...............6

1.2.4 Review by the Nuclear Waste Technical

Review Board .....................6

2. STATUS OF SITE CHARACTERIZATION ............

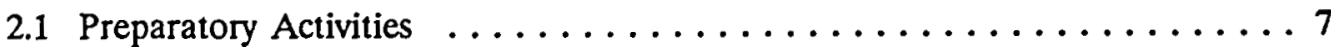

2.1.1 Quality Assurance Program ................ 7

2.1.2 Exploratory Shaft Facility Design and

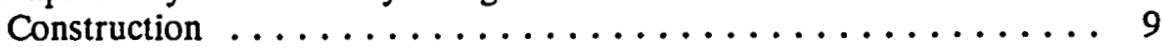

2.1.3 Surface-Based and Underground Testing Program $\ldots \ldots \ldots \ldots \ldots 11$

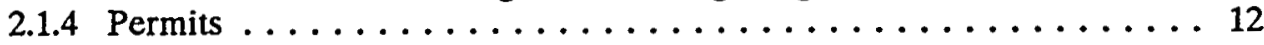

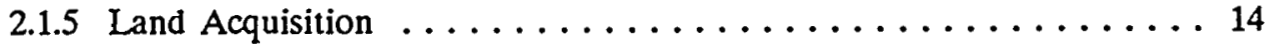

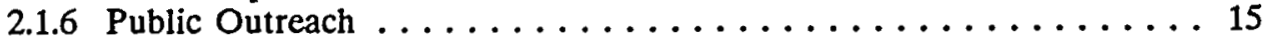

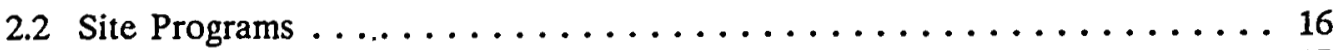

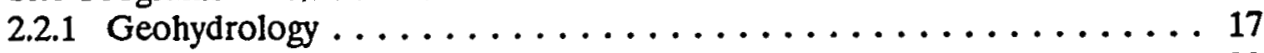

2.2 .2 Geochemistry . . . . . . . . . . . . . . . . . 22

2.2 .3 Rock Characteristics .................... 26

2.2 .4 Climate . . . . . . . . . . . . . . . . . . . 27

2.2 .5 Postclosure Tectonics . . . . . . . . . . . . . . . . . 29

2.2.6 Thermal and Mechanical Rock Properties ............ 30

2.2 .7 Preclosure Tectonics . . . . . . . . . . . . . . . 32

2.3 Repository Design . . . . . . . . . . . . . . . . . 34

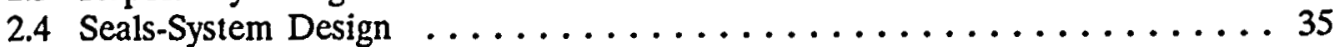

2.5 Waste-Package Design .......................... 36

2.5.1 Postemplacement Near-Field Environment . . . . . . . . . 37

2.5.2 Characteristics and Behavior of the Waste Form ......... 38

2.5.3 Characteristics and Behavior of Disposal-

Container Materials ........................ 39

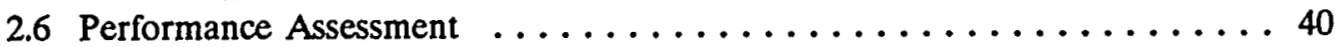

2.6.1 Preclosure Safety Assessment $\ldots \ldots \ldots \ldots \ldots \ldots \ldots \ldots \ldots \ldots . \ldots 40$

2.6.2 Postclosure Performance Assessment . . . . . . . . . . . 41

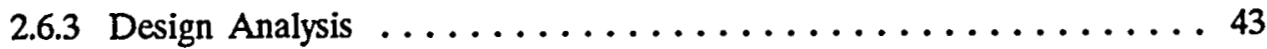

2.6.4 Site Characteristics Analysis . . . . . . . . . . . . 43

3. SCHEDULES $\ldots \ldots \ldots \ldots \ldots \ldots \ldots \ldots \ldots \ldots \ldots \ldots \ldots$

REFERENCES ........................... 49

ACRONYM LIST $\ldots \ldots \ldots \ldots \ldots \ldots \ldots \ldots \ldots \ldots \ldots \ldots$

BIBLIOGRAPHY $\ldots \ldots \ldots \ldots \ldots \ldots \ldots \ldots \ldots \ldots \ldots \ldots \ldots \ldots \ldots \ldots$

$-\mathbf{v}$ 


\section{EXECUTIVE SUMMARY}

In accordance with the requirements of Section 113(b)(3) of the Nuclear Waste Policy Act of 1982 (Pub. L. No. 97-425), as amendcd, the Department of Energy (DOE) has prepared this report on the progress of site characterization activities at Yucca Mountain in southern Nevada. This report is the first of a scries of reports that will hereafter be issued at intervals of approximately 6-months during site characterization. The DOE had planned to issue the first progress report in July 1989. However, because of an ongoing review of the Civilian Radioactive Waste Management Program by the Secretary of Energy, the issuance of the report was delayed. This report is a combination of the first two progress reports, covering the periods of September 15, 1988, through April 15, 1989, and April 16, 1989, through September 30,1989. This and future progress reports will be submitted to the Nuclear Regulatory Commission (NRC) and to the Governor and legislature of Nevada. It will also be made available to the Nuclear Waste Technical Review Board, affected units of local government, and the general public.

The DOE's plans for site characterization are described in the Site Characterization Plan (SCP) for the Yucca Mountain sitc. The SCP has been reviewed and commented on by the NRC, the State of Nevada, the affected units of local government, other interested parties, and the public. More detailed information on plans for site characterization is being presented in study plans for the various site characterization activities.

The progress report presents short summaries of the status of site characterization activities and cites technical reports and research products that provide more detailed information on the activities. The report provides highlights of work started during the reporting period, work in progress, and work completed and documented during the reporting period. In addition, the report is the vehicle for discussing major changes, if any, to the DOE's site characterization program resulting from ongoing collection and evaluation of site information; the development of repository and waste-package designs; receipt of performance-assessment results; and changes, if any, that occur in response to external comments on the site characterization program.

The progress report conveys information in a convenient summary form to be used for information purposes only. It is not intended to be the mechanism for controlling and documenting technical or policy positions regarding changes in schedules or the testing program. Such changes are controlled through rigorous DOE change-control procedures. The progress report only describes such approved changes.

During the reporting periods of this progress report, the DOE continued preparations for beginning new site characterization activities. New site characterization activities will be initiated when (1) necessary activity authorizations have been obtained, (2) the necessary quality assurance controls are in place, and (3) appropriate study plans and procedures are available.

Highlights during the reporting periods included the following:

- The SCP for the Yucca Mountain site was issued on December 28, 1988. The public comment period for the SCP expired on June 1,1989. The DOE received comments from the NRC on July 31,1989 , and from the State of Nevada on May 30, 1989, and September 1, 1989. In addition, comments from other Federal agencies, interested parties, and the general public have been received. The evaluation of all SCP comments was initiated. If there are any major changes to 
the site characterization program resulting from external comments, they will be addressed in future progress rcports.

- A detailed review of repository program schedules was initiated. The goal of this review is to develop a realistic schedule for the repository program that will, along with other initiatives being taken, establish confidence in the DOE's ability to meet program milestones. (Note: the results of this review are provided in the Secretary of Energy's November 1989 report to titled "Report to Congress on Reassessment of the Civilian Radioactive Waste Management Program." Section 3, "Schedules," of this progress report presents the new dates for major milestones in the repository program.)

- The preparation of study plans and technical procedures continued. As of September 30,1989, 7 study plans had been submitted to the NRC for review and comment, and 25 study plans were in the DOE review and approval process.

- Efforts to obtain environmental permits from the State of Nevada continued without success. These permits include an amendment to the current Nevada Test Site airquality permit to conduct prototype dry drilling and coring on the Test Site, an airquality permit for land disturbances, and a water appropriations permit.

- The U.S. Fish and Wildlife Service announced its emergency listing of the desert tortoise as an endangered species. The desert tortoise inhabits the desert southwest, including the Yucca Mountain site. As a result of this listing, the DOE has restricted access to the Yucca Mountain site and is preparing a biological assessment to evaluate the Project's potential effects on the tortoise and alternatives for avoiding or minimizing impacts.

- Interactions were initiated with the Nuclear Waste Technical Review Board, the independent review board established by the Nuclear Waste Policy Act, as amended. During the reporting period, the full Board and its various panels met with the DOE on seven occasions.

- Implementation of the quality assurance program continued. The NRC accepted the Office of Civilian Radioactive Waste Management's Quality Assurance Requirements and Quality Assurance Program Description documents. The NRC also accepted the Project Office's Nevada Nuclear Waste Storage Investigations Quality Assurance Plan 88-9, Revision 2. All Quality Assurance Program Plans of individual program participants have been approved by the DOE and submitted to the NRC for acceptance. Audits and surveillances continued.

- Prototype dry drilling and coring was initiated. The testing was conducted in Utah and included drilling in unsaturated volcanic rock. The testing so far has provided valuable data and experience in wire-line coring and sample recovery using drydrilling techniques.

- Prototype testing activities to develop techniques and procedures in preparation for exploratory shaft facility testing continued in G-Tunnel on the Nevada Test Site. 


\section{INTRODUCTION}

\subsection{PURPOSE AND SCOPE OF THE PROGRESS REPORT}

In accordance with the requirements of Section 113(b)(3) of the Nuclear Waste Policy Act of 1982 (Pub. L. No. 97-425), as amended, the Department of Energy (DOE) has prepared this report on the progress of site characterization activities at Yucca Mountain in southern Nevada. This report is the first of a series of reports that will hereafter be issued at intervals of approximately 6-months during site characterization. The DOE had planned to issue the first progress report in July 1989. However, because of an ongoing review of the Civilian Radioactive Waste Management Program by the Secretary of Energy, the issuance of the report was delayed. This report is a combination of the first two progress reports, covering the periods of September 15, 1988, through April 15, 1989, and April 16, 1989, through September 30, 1989. This and future progress reports will be submitted to the Nuclear Regulatory Commission (NRC) and to the Governor and legislature of Nevada. It will also be made available to the Nuclear Waste Technical Review Board, affected units of local government, and the general public.

The progress report presents short summaries of the status of site characterization activities and cites the technical reports and research products that provide more detailed information on the activities. The report provides highlights of work started during the reporting period, work in progress, and work completed and documented during the reporting period. In addition, the report is the vehicle for the discussion of major changes, if any, to the DOE's site characterization program resulting from ongoing collection and evaluation of site information; the development of repository and waste-package designs; the receipt of performance-assessment results; and any changes that occur in response to external comments.

The progress report conveys information in a convenient summary form to be used for information purposes only. It is not the mechanism for controlling and documenting technical or policy positions regarding changes in schedules or the testing program. Such changes are controlled through DOE change-control procedures. The progress report only describes such approved changes.

The progress report consists of three sections: (1) an introductory section, (2) a section on the status of site characterization activities, and (3) a section providing updated schedule information relevant to site characterization. Complete lists of the documents cited (which are available for inspection at DOE public reading rooms in Washington, D.C., and the State of Nevada) and acronyms used in the text are also provided. In addition, the report includes a selective annotated bibliography of recent publications relevant to site characterization.

\subsection{BACKGROUND INFORMATION}

As stated in Section 160 of the Nuclear Waste Policy Act of 1982 (NWPA), as added by the Nuclear Waste Policy Amendments Act of 1987 (the Amendments Act, Pub. L. No. 100-203), the Yucca Mountain site in Nevada has been selected for detailed study as the candidate site for the United State's first geologic repository for spent nuclear fuel and 
high-level radioactive waste. The Yucca Mountain site has not been selected for a repository; rather, it has been designated as the only candidate site for study to assess its suitability for development as a repository.

The purpose of this detailed study is to obtain the information necessary to determine whether the Yucca Mountain site is suitable for a geologic repository and, if so, to provide the information necessary to prepare a license application for submittal to the NRC. If during site characterization the Yucca Mountain site is determined to be unsuitable for development as a geologic repository, the DOE will, among other actions, (1) terminate all site characterization activities at the site, (2) notify the Congress and the State of Nevada of such termination, and (3) reclaim the site to mitigate any significant adverse environmental impacts caused by site characterization studies. After the completion of site characterization, if the DOE believes that the Yucca Mountain site is suitable for development of a repository, a recommendation for approval of the site will be sent to the President. The recommendation will be accompanied by an environmental impact statement. After recommendation by the DOE, if the President considers the site qualified, the President will recommend the site to the Congress, which only must act on the recommendation if the State of Nevada disapproves of the site recommendation. If the Presidential recommendation becomes effective, the DOE will submit a license application to the NRC to obtain authorization to construct a repository at the site.

\subsubsection{Site characterization}

The detailed study mentioned in the preceding section is referred to as site characterization. It is a comprehensive program of activities to collect site information. These activities are integrated with activities to design a potential repository, a repository seals system, and a waste package (i.e., the waste form and the container in which it is packaged for disposal) and with the activities associated with performance assessments.

The site information consists of data on the natural features of the site, such as those related to the geologic, hydrologic, geochemical, climatological, and meteorological conditions at the site. This information is obtained by conducting both surface-based and underground field tests as well as tests in the laboratory. The underground investigations will be conducted in an exploratory shaft facility (ESF). In the current conceptual design, the ESF consists of two exploratory shafts, excavated to the depth of the proposed repository horizon, providing access to underground testing rooms and tunnels. The ESF also will include various structures and buildings on the surface, such as a hoist house for the shafts and temporary buildings for laboratories and offices.

No significant adverse environmental effects are expected to result from site characterization (DOE, 1986). However, the DOE, in consultation with the State of Nevada and affected units of local government, will conduct activities during site characterization to monitor environmental conditions and will implement appropriate mitigation measures that may be necessary. Plans for environmental monitoring and mitigation are described in the Environmental Monitoring and Mitigation Plan (DOE, 1988a). In addition, in response to Section 175 of the NWPA, as added by the Amendments Act, the DOE submitted a report to the U.S. Congress identifying potential socioeconomic effects that may result from the repository program (DOE, 1988b). These potential effects will also be monitored. Results of monitoring activities will be reported semiannually in environmental and socioeconomic progress reports. 


\subsubsection{The Site Characterization Plan}

In preparation for site characterization, the DOE issued the Site Characterization Plan (SCP) for the Yucca Mountain site (DOE, 1988c) in December 1988. An SCP overview (a summary of the SCP) and an informational public handbook also were released. Notices of the availability of the SCP and the accompanying documents were published in the Federal Register, and the Nevada news media were notified.

The SCP consists of eight chapters. Chapters 1 through 7 of the SCP discuss the current understanding of the technical characteristics and features of the site and a preliminary conceptual design of the repository and waste package in sufficient detail so that the basis for the site characterization program can be understood. Chapter 8 of the SCP describes, in general, the tests and analyses that the DOE is conducting during site characterization and the rationale used to identify them. More-detailed descriptions of the tests and analyses are provided in study plans and technical procedures. Chapter 8 also discusses the design and construction of the ESF, the potential impacts of site characterization on the waste-isolation capabilities of the site, the schedule for site characterization activities, the quality assurance program for site characterization, and the plans for decommissioning facilities used for characterization if the Yucca Mountain site is found to be not suitable as a repository site.

On June 1, 1989, the public comment period for the SCP expired. The NRC issued its critique of the SCP, the Site Characterization Analysis, on July 31, 1989 (NRC, 1989). The NRC raised objections to two aspects of the DOE program, one regarding the design of the ESF and the other regarding the DOE quality assurance program. On May 30, 1989, the State of Nevada provided comments on the design of the ESF (Loux, 1989a). On September 1, 1989, the State of Nevada provided its comments on the SCP (Loux, 1989b). In addition, comments have been provided by other Federal agencies, interested parties, and the general public. Efforts to review and evaluate all comments from all parties have been initiated.

\subsubsection{Participation by the State of Nevada and affected units of local government}

The Amendments Act established a specific role in the repository program for the State of Nevada and affected units of local government (so far determined to be Nye County, Clark County, and Lincoln County). This role includes, among other things, review of (1) the DOE's technical documents, including the SCP; (2) the results of site characterization activities; (3) the designs for the repository and the waste package; and (4) the results of performance assessments.

\subsubsection{Review by the Nuclear Waste Technical Review Board}

The Amendments Act established a Nuclear Waste Technical Review Board that is independent of the DOE. The Board is to consist of 11 members appointed by the President from at least 22 candidates nominated by the National Academy of Sciences. The Board is to evaluate the technical and scientific validity of DOE activities. These activities include site characterization activities and activities related to waste packaging and transportation. Twice a year, the Board is to report its findings and conclusions to the Secretary of Energy and to the Congress. 
On January 18,1989 , the President appointed eight individuals to the Board: $D$. U. Deere, of the University of Florida, who has been designated Chairman; C. L. Allen, of the California Institute of Technology; J. E. Cantlon, of Michigan State University; M. W. Carter, professor emeritus at the Georgia Institute of Technology; D. Langmuir, of the Colorado School of Mines; D. W. North, of Decision Focus, Inc.; D. L. Price, of the Virginia Polytechnic Institute and State University; and E. D. Verink, of the University of Florida. times:

During the reporting periods, the Board and its various panels convened several

March 7-8, 1989

The Board met with the DOE to receive a briefing on the overall waste-management program.

April 11-12, 1989 The Structural Geology and Geoengineering Panel was briefed by the DOE on the plans for underground excavations during site characterization and methods for constructing the exploratory shafts.

May 16-17, 1989

The Risk and Performance Analysis Panel was briefed by the DOE on activities related to performance assessment.

June 26-28, 1989

The DOE briefed the Board on the geologic conditions at Yucca Mountain and the site characterization plans for further evaluating those conditions. In addition, the State of Nevada briefed the Board on its concerns regarding the repository program. A field trip to Yucca Mountain was also conducted.

August 21-23, 1989 The Containers and Transportation Panel was briefed by the DOE on high-level radioactive waste shipping cask development, waste package development (including container corrosion), and transportation planning.

September 12-13, 1989 The Board convened to establish internal procedures and to review the information gathered to date on the repository program.

September 14, 1989 The Environmental and Public Health Panel was briefed by the DOE on health, safety, and environmental regulatory activities related to exploratory work at the Yucca Mountain site.

DOE efforts to respond to concerns raised by the Board and requests for further information were initiated during the reporting periods. Interactions with the Board will continue throughout site characterization. 


\section{STATUS OF SITE CHARACTERIZATION}

\subsection{PREPARATORY ACTIVITIES}

\subsubsection{Quality assurance program}

During the reporting periods, the DOE continued the effort of qualifying the quality assurance (QA) programs of the DOE Office of Civilian Radioactive Waste Management (OCRWM), the DOE Yucca Mountain Project Office (Project Office), and participating organizations. Qualification of QA programs is required before new site characterization activities can be initiated. Data that are obtained through activities conducted before a fully qualified QA program is in place must be qualified if the data are to be used in licensing (NRC, 1988a).

The DOE and the NRC initiated regularly scheduled meetings to discuss QArelated issues and the status of the QA program's qualification. Five such meetings were conducted in 1989: February 23, March 22, May 9, July 11, and September 7.

The OCRWM developed and issued the Quality Assurance Requirements (QAR) document on November 3, 1988, and the Quality Assurance Program Description (QAPD) document on December 20, 1988. The QAR defines the QA requirements governing activities affecting quality, and the QAPD describes the OCRWM responsibilities, interfaces, and provisions necessary to implement the requirements of the QAR. In May 1989, the NRC issued Safety Evaluation Reports that accepted the QAR and QAPD documents. To implement the requirements of the QAPD, the OCRWM continued the preparation of subordinate QA procedures. As of September 30, 1989, 21 QA administrative procedures and 1 implementing line procedure had been issued for use.

The Project Office issued Revision 2 of the Nevada Nuclear Waste Storage Investigations Quality Assurance Plan (QAP) 88-9 on December 7, 1988. The QAP defines, for the entire Yucca Mountain Project, the QA requirements governing activities affecting quality and the responsibilities, interfaces, and provisions necessary to implement the requirements. The NRC accepted the QAP with issuance of a Safety Evaluation Report on October 14, 1988, and a supplement to the Safety Evaluation Report on December 30, 1988.

Work continued on the revision of Project Office and individual participant organizations QA Program Plans to meet the requirements of QAP 88-9, Rev. 2. As of September 30, 1989, QA Program Plans for all individual participants were under review by the NRC.

QAP 88-9, Rev. 2, specifies certain control measures for computer software, such as the development of a software QA plan by all participants. To date, one such plan, prepared by the U.S. Geological Survey, has been developed and approved by the DOE. Six additional plans are currently in review or in some stage of development. Once approved, the plans and procedures are subject to audit.

During the reporting periods, the Project Office and participating organizations initiated a review of existing QA implementing procedures to determine whether existing 
procedures need to be revised to meet current requirements and whether new procedures need to be developed. All quality-related procedures have been grouped into four categories:

1. Procedures required for the start of the Title II design of the ESF.

2. Procedures required for the start of long-lead-time procurement.

3. Procedures required for the start of site-preparation activities.

4. The balance of procedures required for QA program qualification.

A two-part verification surveillance by a DOE surveillance task force was completed on the procedures identified in each of the above categories. The first part of this surveillance consisted of a documented review of each procedure to ensure the incorporation of all applicable requirements of QAP 88-9, Rev. 2. The second part of this surveillance consisted of a review of the implementation of procedural requirements where such documentation exists. All deficiencies discovered, as well as the actions taken to correct the deficiencies, were formally documented.

The implementation of NUREG-1318, the NRC technical position on QA for a geologic repository (NRC, 1988b), was initiated during the reporting periods. The NRC technical position provides guidance for the identification of items important to safety, items important to waste isolation, and activities related to natural barriers important to waste isolation. To implement the NRC technical position, the Project Office developed four administrative procedures: (1) AP-6.8Q, "Identification of Items Important to Waste Isolation"; (2) AP-6.9Q, "Candidate List of Items and Activities Subject to the Quality Assignment Process"; (3) AP-6.10Q, "Identification of Items Important to Safety"; and (4) AP-6.11Q, "Identification of Activities To Be Placed on the Quality Activities List."

These administrative procedures were implemented to identify those elements and activities related to the ESF that are items important to safety or activities to be placed on the Quality Activities List. However, because of difficulties in implementing the four procedures, they are being consolidated into a single procedure, AP-6.17Q, titled "Determination of the Importance of Items and Activities." In addition, procedure AP-5.28Q, "Quality Assurance Grading." is being developed to address the assignment of QA levels and the grading of $\mathrm{QA}$ requirements.

The OCRWM developed and implemented a schedule for surveillances of both OCRWM and Project Office activities to support QA program qualifications before the initiation of new site characterization activities. A schedule for the qualification audits of the QA programs of the OCRWM, the Project Office, and the project participants was also developed. During the reporting periods, the Project Office completed 8 audits of participating organizations and contractor QA programs and a total of 136 surveillances of specific activities. The OCRWM performed 15 surveillances of specific program activities.

An application package to create a new DOE records system that would allow auditing of the qualification and training records of DOE personnel was completed during the reporting periods. The need for a new records system arises from requirements contained in the Privacy Act of 1974. The application package is in DOE management concurrence. 


\subsubsection{ESF design and construction}

The Title I design for the ESF was completed with the release of a summary report of the design on December 21, 1988 (DOE, 1988d). Prior to the release of this report, the NRC raised a concern regarding the DOE's design-control process used in developing the ESF Title I design, including the incorporation of the requirements of $10 \mathrm{CFR}$ Part 60 into the design. Mectings between the DOE and the NRC on this topic were held on October 19-21, 1988; November 3, 1988; November 23, 1988; and December 18, 1988.

On December 12,1988, the DOE initiated a technical assessment review of the ESF Title I design in accordance with Project Office procedure QMP-02-08, "Technical Assessment Review." The purpose of this review was twofold: (1) to perform a designacceptability analysis of the ESF Title I design to address the concern of the NRC regarding the design-control process and (2) to perform an evaluation of alternative exploratory-shaft locations, with respect to differences in waste-isolation potential and potential adverse effects of shaft sinking. (This evaluation included an assessment of what influence, if any, these differences might have had on the selection of the preferred shaft location, had the differences been explicitly considered in the location-selection process.)

The technical assessment review concluded that the ESF Title I design sufficiently incorporated the applicable requirements of 10 CFR Part 60, given that the Title I design was preliminary. Regarding exploratory-shaft location, it was concluded that waste-isolation potential was not a discriminating factor among alternative exploratory-shaft locations and, had it been explicitly considered, would not have affected the selection of the preferred shaft location. On the basis of this review, the DOE determined that there was no need to make any changes to the ESF Title I design that would require significant modification of the schedule, configuration, or technical approach for the site characterization activities described in the SCP. The results of the review of the ESF Title I design are documented in a review record memorandum dated February 3, 1989 (DOE, 1989a).

A meeting was held in Las Vegas, Nevada, on July 6 and 7,1989, to discuss the DOE's ESF design-control process. Representatives of the NRC, the DOE, the State of Nevada, and the City of Las Vegas, Nevada, attended the meeting. During the meeting, the DOE presented its revised design-control process. The NRC stated that the revised process appeared to be adequate. An agreement was also reached with the NRC by which the NRC will participate as observers during key stages in the design-review process.

During the reporting periods, the DOE conducted evaluations of alternative methods for exploratory construction and the benefits of extended exploratory drifting. These evaluations were conducted in response to suggestions made by the Structural Geology and Geoengineering Panel of the Nuclear Waste Technical Review Board at a meeting held on April 11 and 12,1989. After reviewing the DOE's plans for constructing the ESF, the Panel offered suggestions for improving in-situ test-data quality, minimizing disturbances to the rock mass, shortening the exploratory shaft construction and testing schedule, and obtaining data that would be more representative of the proposed repository block. Specifically, the DOE's evaluations addressed the Panel's suggestions of (1) using mechanical mining methods to construct one or both of the exploratory shafts; (2) deferring or relocating noncritical tests currently planned for the exploratory shaft, and (3) extending exploratory drifting to the south and west.

As a result of the evaluations, it was concluded that mechanically mined shafts generally require less excavation time than do conventionally mined shafts. It was determined that the sequencing of tests during shaft construction, rather than the method of shaft construction, has a more significant effect on the total time required to complete 
shaft construction (Golder, 1989). It was also concluded that all construction methods and test sequences considered would permit the collection of test data of sufficient quality for a license application (Golder, 1989). With respect to extending exploratory drifting, it was concluded that it is desirable to plan for an additional exploratory drift to intersect the Ghost Dance fault at a second location to the south, along the proposed main repository drift (Weston, 1989).

In a letter dated August 11, 1989, D. Deere, Chairman of the Nuclear Waste Technical Review Board, requested that the DOE reexamine the proposed ESF configuration (Deere, 1989). The DOE was asked to evaluate the merits of using a shaft-boring machine to construct the principal testing shaft, and incorporating an inclined access drift in the proposed ESF configuration, in lieu of a second shaft, excavated by the use of a tunnel-boring machine or other mechanical excavation equipment. In response to these requests, and to alleviate the concerns in these areas expressed by the NRC, the State of Nevada, and internally within the DOE, the DOE initiated a reevaluation of alternative ESF configurations and construction methods. Plans for conducting the evaluation, including the definition of purpose, scope, and methodology, were established in preparation for the actual evaluation.

In response to a concern expressed by the NRC regarding an inferred fault in the vicinity of the proposed location of the exploratory shafts, the DOE initiated a technical assessment review. A technical assessment review notice, "Geologic and Geophysical Evidence Pertaining to Structural Geology in the Vicinity of the Proposed Exploratory Shaft" (DOE, 1989b), was issued by the DOE on May 18, 1989. The principal purposes of the review are (1) to assess the data and the interpretations that were the bases for the inferred fault; (2) to determine how the data were considered in the ESF location selection process; (3) to make a determination of the presence of faulting in the vicinity of the proposed exploratory-shaft locations; and (4) if it is determined that a fault exists in the vicinity, to evaluate the impacts on the ESF Title II design process. The technical assessment review was in progress at the end of the period covered by this report.

Preparations for the start of the ESF Title II design resulted in significant progress in various areas during the reporting period. The design of the Integrated Data System, a computer-based central data-collection utility, was submitted to a technical assessment review, the results of which were issued on February 24, 1989 (DOE, 1989c). The ESF Subsystems Design Requirements Document for Title Il design (DOE, 1989d), which presents the functional requirements and performance criteria for systems and subsystems within the scope of the ESF, was revised to include numerous criteria developed as a result of the technical assessment review of the ESF Title I design and other activities. The revised Subsystems Design Requirements Document underwent an extensive review and was issued as Revision 0 on April 11, 1989, to support the start of ESF Title II design. Version 4 of the Reference Information Base, a data base that maintains the values for site-specific parameters to be used for design and performance assessment, was issued on February 1, 1989 (DOE, 1989e), after coordination with the staff responsible for ESF Title II design activities.

A management review of the prerequisites for the start of ESF Title II design was conducted during March and April of 1989. As a result of this review, the DOE began the Title II design for ESF surface facilities in late April 1989. 


\subsubsection{Surface-based and underground testing program}

The Surface-Based Investigations Plan (SBIP) (DOE. 1988e) was issued in December 1988. The SBIP covers all activities that are related to surface (e.g., mapping, trenching) and surface-based (e.g., drilling) site characterization work (excluding the activities related to the ESF) and are described in Chapter 8 of the SCP. The SBIP is not a substitute for the information presented in the SCP, nor is it used in lieu of study plans. The SBIP includes the following information for each field activity: references to the SCP and other planning documents; responsible project participants; basic activity information, including the type, location, and purpose of the planned activity; relevant technical information (e.g., equipment to be used, borehole depths, and survey-area descriptions); and the projected schedule. The SBIP also includes a summary of planned activities, a general discussion of the technical rationale for various activities, and a portfolio of detailed maps showing the locations of planned surface-based testing and construction activities.

During the reporting periods, the DOE initiated the prototype dry-drilling and dry-coring program. Dry drilling and coring is highly advantageous for deep drilling and core sampling in the unsaturated zone at the Yucca Mountain site, limiting the potential of altering rock parameters, such as moisture content, and reducing water usage. Dualwall reverse circulation is the drilling method used in the prototype drilling tests. To meet the drilling requirements of the Project, the DOE has contracted with Lang Exploratory Drilling, Inc., for drilling prototype holes and further development of the dualwall reverse-circulation drilling technique.

A location was originally selected in Area 25 south of Busted Butte on the Nevada Test Site (NTS) to conduct prototype drilling. However, drilling at this site has been delayed because of the lack of an operating permit for Yucca Mountain Project activities, as required by Nevada air-quality regulations. As a result, the first drilling was done at a mine site near Tooele, Utah. This location was selected because of its close proximity to the drilling contractor's shop, thus facilitating equipment modification and fabrication, as necessary, during drilling. During this phase of equipment development, 8- and 12-inchdiameter holes were drilled in the rock at the site, a silicified limestone in the unsaturated zone. As a result of this first prototype drilling, it was determined that the dry-drilling methodology has a high probability of success at Yucca Mountain. However, some drillbit modifications were made in preparation for additional prototype drilling.

A second prototype drilling site was selected in volcanic rocks at an old mining area approximately 15 miles west of Milford, Utah. Four holes were drilled to various depths in the unsaturated zone. However, because water was encountered in each of these holes, they were all abandoned before reaching depths greater than 550 feet. Despite not reaching desired depths, considerable experience was gained in wireline coring and in sample recovery using dry-drilling technology.

Efforts will continue to select a site where rock type and ground-water depths are sufficient to further test the dry-drilling and dry-coring technology at depths and conditions similar to those that will be encountered at Yucca Mountain. Since the State of Nevada had not granted the DOE the necessary air-quality related operating permit to allow drilling on the NTS, alternative sites in southern Utah and Arizona are being examined to continue the prototype dry-drilling program.

Yucca Mountain drill cores and related records that were stored in the Nevada Test Site core library were transferred to the Sample Management Facility, a central storage facility for samples obtained during site characterization. Technical and administrative procedures for the operation and use of the facility were implemented during the reporting 
periods. A readiness review for the facility was conducted, and the facility is now fully operational. Staff are now in the process of testing procedures with core and cutting samples collected during the prototype drilling program.

During the reporting periods, an action plan was developed to verify field locations for surface-based site characterization activities. These field locations are expected to be established during the next reporting period and will be based on the preliminary coordinates presented in the SBIP (DOE, 1988e) and the Yucca Mountain Site Atlas (DOE, 1988f).

Prerequisite review action plans, which consist of information, requirements, and check lists compiled by principal investigators to determine the readiness to begin field work in a specific activity, were developed for the following surface-based site characterization activities:

1. Site vertical borehole studies, SCP Activity 8.3.1.2.2.3.2.

2. Multipurpose borehole testing, SCP Activity 8.3.1.2.2.4.9.

3. Geologic mapping of zonal features within the Paintbrush tuff, SCP Activity 8.3.1.4.2.2.1.

4. Surface fracture network studies, SCP Activity 8.3.1.4.2.2.2.

5. Evaluation of past discharge areas, SCP Activity 8.3.1.5.2.1.3.

6. Calcite and opaline silica vein deposits, SCP Activity 8.3.1.5.2.1.5.

7. Location and recency of faulting near prospective surface facilities, SCP Activities 8.3.1.17.4.2.1 and 8.3.1.17.4.2.2.

8. Quaternary geology and faulting at Yucca Mountain, SCP Activity 8.3.1.17.4.6.1.

The major purpose of prerequisite review action plans is to (1) assist Project management in integrating site characterization activities and prevent delays and interruptions that may affect personnel, schedule, cost, or the licensability of the site and (2) ensure that these activities meet their technical objectives as described in the SCP and programmatic requirements. The prerequisite action plans will also be used for readiness evaluations and work authorizations.

Prototype testing activities to develop techniques and procedures in preparation for ESF testing continued in G-Tunnel on the NTS. During the reporting period, emphasis was placed on the development of equipment and techniques to perform dry overcoring in the exploratory shafts for the overcore stress test, the intact-fracture test, and the diffusion test. Emphasis was also placed on the development of procedures for the collection of bulkrock samples from the ESF for laboratory analysis. G-Tunnel expansion to provide space for prototype testing of the engineered barrier and thermal stress tests was started. Alcove mining for the optimum rubble prototype test was completed. As part of this test, controlled blasting techniques were used to evaluate practices for the control of dust from dry blast-hole drilling and to obtain rubble sizes suitable for preparing samples for the matrix hydrologic properties test.

\subsubsection{Permits}

During the reporting periods, environmental regulatory compliance activities were conducted in an effort to obtain environmental regulatory approvals for site characterization activities at Yucca Mountain. 
On July 24, 1989, the U.S. Fish and Wildlife Service (USFWS) announced its intention to list the desert tortoise, which inhabits the desert areas of southwestern United States, including the Yucca Mountain area, as an endangered species under the Federal Endangered Species Act (ESA). On August 4, 1989, USFWS published a notice in the Federal Register that it was exercising its emergency authority to list the desert tortoise as an endangered species for 240 days. The USFWS is soon expected to propose a formal (nonemergency) listing of the desert tortoise as "endangered." Such a listing would have the effect of extending the tortoise's endangered status past the 240- day period of the emergency listing. On August 9, 1989, the DOE initiated an ESA Section 7 consultation with the USFWS concerning the Project's potential effect on the species. As a result of these actions, a biological assessment is being prepared to evaluate the Project's potential effects on the tortoise and available alternatives for avoiding or minimizing impacts to the tortoise. The biological assessment is scheduled to be submitted to the USFWS in October 1989. The Yucca Mountain site is not expected to be designated as a critical habitat for the desert tortoise. However, in the interim, access to the Yucca Mountain site has been restricted until consultations with the USFWS are concluded.

The Nevada Division of Environmental Protection (NDEP) continues to withhold the Project's air-quality permit application for land disturbance and to take no action on the DOE's request for a modification of the NTS air-quality operating permit for prototype activities. On July 11, 1989, a letter was sent to the NDEP stating that the application for an air-quality permit for land disturbance was complete and that no legal basis exists for not approving the application. However, the NDEP stated in a telephone conversation on the same day that Nevada State Bill A.B. 222, effective July 1, 1989, makes the repository unlawful in the State of Nevada. Therefore, consultation between the NDEP and the State Attorney General is necessary to determine whether the application or the permit modification request can be issued.

On June 27, 1989, a Resource Conservation and Recovery Act Identification Number was received from the U.S Environmental Protection Agency for the handling and management of hazardous waste. Any hazardous or solid wastes generated during the course of site characterization will be collected, stored, transported, and disposed of in accordance with the Project Hazardous Materials Management and Handling Program. A draft description of this program is scheduled for completion in early 1990.

The Nevada State Engineer continues to process the DOE's application for a Ground-Water Appropriation Permit. Protests against the permit have been received from the National Park Service, the Nevada Nuclear Waste Project Office, and the State of Nevada, which filed as a formal party to the proceedings on March 15, 1989. The State Engineer plans to hold a public hearing on this issue, but to date no schedule has been established for the hearing.

Discussions continue with the National Park Service to address its concern that Project water use during site characterization may affect ground-water resources in Devil's Hole, which is part of the Death Valley National Monument, and in Ash Meadows. The National Park Service is protesting all new applications in the region but has stated that establishing a monitoring program would satisfy its concerns. Consequently, a watermonitoring program is being developed, in consultation with the National Park Service, to satisfy this suggested permit condition. Development of the monitoring program is scheduled for completion in October 1989.

On February 9, 1989, the DOE published a notice in the Federal Register stating that it proposes to conduct activities in a floodplain. The Nevada Nuclear Waste Project Office provided comments on the notice on March 31, 1989. The floodplain/wetlands 
assessment necessary to satisfy both Executive Order 11988, "Floodplain Management," and the DOE regulations contained in $10 \mathrm{CFR}$ Part 1022, "Compliance with Floodplain/Wetlands Environmental Review Requirements," has been prepared and is scheduled for release in Decemher 1989.

The application for a Free Use Permit the for use of sand, gravel, and fill material on land administered by the U.S. Bureau of Land Management (BLM) during site characterization, which is required pursuant to the Materials Act, was filed with the BLM on July 11,1989 . On August 29,1989 , the BLM toured the gravel-pit location. Permit approval is expected as soon as consultations with the USFWS on the desert tortoise are complete.

On April 6, 1989, an application for an Underground Injection Control Permit was filed with the NDEP for tracer tests in the unsaturated zone. This permit was requested for the conservative and reactive tracer tests to be conducted in the wells of the C-hole complex. On June 27, 1989, the NDEP notified the DOE Nevada Operations Office Environmental Compliance Division, which, in turn, notified the Project Office on July 20, 1989 , that the application was incomplete. The NDEP has requested additional information about the injection wells and an abandonment plan. These items are being prepared and are expected to be submitted to the NDEP in December 1989.

A Programmatic Agreement between the DOE and the Advisory Council on Historic Preservation was signed December 15, 1988. The Programmatic Agreement identifies the actions the DOE will undertake during site characterization to comply with the National Historic Preservation Act and other acts related to historic preservation and archaeology.

\subsubsection{Land acquisition}

During the reporting periods, quarterly consultation meetings were held with the Las Vegas District and Stateline Area Resource Offices of the BLM concerning Right-of-Way Reservation (ROWR) N-47748. ROWR N-47748 was granted to the DOE by the Nevada State Office of the BLM in February 1988 for access to the public lands at Yucca Mountain. The process to gain Project access to the Nellis Air Force Base Range is continuing. It is expected that an ROWR will be issued by the BLM for the Nellis range in October 1989.

Under the authority of the Federal Land Policy and Management Act, the DOE filed an application for a temporary land withdrawal with the Nevada State Office of the BLM on December 27,1988 . The application requested the withdrawal of approximately 4,255 acres of public land from settlement, sale, location, or entry (including any use under the mining and mineral leasing laws) for a period of 12 years. The temporary land withdrawal was requested to formally notify the public of particularly sensitive areas in and around the Yucca Mountain site that could be adversely affected by activities other than those planned by the DOE for characterizing the site. The withdrawal would also prevent public activities from interfering with the planned site characterization activities. Notice of this application was published in the Federal Register on January 13, 1989. This publication started a 2-year segregation period during which the DOE must provide a case file (i.e., the documentation) for completion of the withdrawal. As part of this case file, a draft Land Withdrawal Report has been prepared and transmitted to the Las Vegas District Office of the BLM for review. In addition, a draft Mineral Resource Analysis, which is also required for the case file, was prepared by the Nevada Bureau of Mines and Geology and entered into the review process. 


\subsubsection{Public Outreach}

In March 1989, three public hearings on the SCP were held at various locations in Nevada: Amargosa Valley (March 20), Las Vegas (March 21), and Reno (March 23). Notices of the schedule for the public hearings were published in the Federal Register and in local Nevada newspapers. At the request of Nevada Governor Miller, contingency arrangements for additional sessions were made to ensure that everyone wishing to speak had the opportunity to do so. Afternoon and evening sessions were held in each location. About 450 people attended the hearings, with a total of 165 people commenting on the SCP and other issues. The proceedings were recorded and transcribed by a certified court reporter. Copies of the transcript are available at the DOE public reading room in Las Vegas; at the Yucca Mountain Information Office in Beatty; at the libraries of the University of Nevada, Las Vegas, and the University of Nevada, Reno; and at six community public libraries in the State.

In February 1989, four Project update meetings were held in Nevada. These 3 hour meetings were held on the evenings of February 15, 16, 21, and 23 in Beatty, Las Vegas, Caliente, and Reno, respectively. Notices of the schedule for the meetings were published in the Federal Register and in local Nevada newspapers. The technical program described in the SCP was highlighted during the meetings. State and local governments were invited to participate in the meetings, and time was provided for questions from the audience. About 350 people attended the four meetings, which received wide media coverage.

In September 1989, three Project update meetings were held in Nevada. The meetings discussed, in part, the status of the site characterization program. These 3 hour meetings were held on the evenings of September 25, 26, and 28 in Pahrump, Henderson, and Carson City, respectively. During the meetings, draft copies of the first progress report on site characterization were available for information (the draft of the first progress report has since been incorporated into this document). In addition, the status of responses to comments raised during the March 1989 SCP Public Hearings was discussed. The public was informed that all comments will receive written responses. However, because of the volume of comments received, comment-response packages are not expected to be issued until early 1990.

Project update meetings will be held approximately every 6 months in various locations around Nevada. The meetings will provide information on the status of site characterization activities, as well as various related topics currently of public interest. Summaries of the issues raised at all update meetings will be prepared and reviewed by scientists responsible for planning the studies at Yucca Mountain to ensure that all technical concerns are appropriately addressed. 


\subsection{SITE PROGRAMS}

The site programs consist of the planned field and laboratory investigations for obtaining the technical information needed to adequately characterize the Yucca Mountain site. This information is integrated with design and performance-assessment activities throughout site characterization. The field and laboratory investigations are organized into 16 distinct site programs, each with a specific technical focus (e.g., geohydrology, geochemistry, rock characteristics). Investigations are subdivided into studies and specific activities. A description of the site programs is provided in Section 8.3.1 of the SCP.

During the reporting periods, significant effort continued on the development, review, and approval of study plans. Study plans are the documents that describe site program studies and activities in greater detail than that provided in the SCP. They are the link between the studies described in the SCP and the technical procedures that will be used in conducting tests in the field and the laboratory. There are 106 studies identified in the SCP for which study plans need to be developed.

On December 15, 1988, the DOE and the NRC held a technical meeting to discuss study plans. The State of Nevada also attended the meeting. During the meeting the following subjects were addressed: (1) the purpose and scope of study plans, (2) quality assurance concerns related to study plans, (3) the procedures of the DOE and the NRC for reviewing study plans, and (4) the schedule for study plan preparation and release.

The development of study plans for ongoing activities is a high priority. An activity is considered to be ongoing if it was in progress at the time the Yucca Mountain site was originally selected as one of the three sites to be characterized. Examples of ongoing activities include (1) hydrologic, meteorologic, and seismic monitoring at the site; (2) geodetic surveys; and (3) laboratory analyses of degradable and irreplaceable samples.

Scientific Investigation Plans control ongoing activities that continue without approved study plans. When a study plan for an ongoing activity is developed and approved by the DOE, the study plan will then replace the Scientific Investigation Plan as the document controlling the activity. Before the initiation of a new site activity, however, a study plan for the activity must be developed, reviewed, and approved by the DOE. All study plans will be submitted to the NRC for comment as they become available. The NRC has agreed to identify any objections within 3 months of receiving each plan and to complete detailed technical reviews of selected plans within 6 months of receipt.

On February 9, 1989, the DOE submitted to the NRC the study plans for water movement tracer tests using chloride and chlorine-36 (8.3.1.2.2.2); characterization of percolation in the unsaturated zone--exploratory shaft study (8.3.1.2.2.4); characterization of site structural features (8.3.1.4.2.2); excavation investigations (8.3.1.15.1.5); and characterization of the site ambient stress (8.3.1.15.2.1). As requested by the NRC at the DOE-NRC meeting on study plans, held on December 15, 1989, the DOE performed an assessment of the process used to develop, review, and approve the above study plans. The assessment concluded that the study plans fulfilled the requirements for the content and level of detail of study plans and that they met all major QA requirements for planning documents. The assessment was provided to the NRC on June 28, 1989.

On June 30,1989, study plans for (1) evaluating the location and recency of faulting near prospective surface facilities (8.3.1.17.4.2) and (2) characterization of the Yucca Mountain Quaternary regional hydrology (8.3.1.5.2.1) were submitted to the NRC for comment. In addition, as of September 30, 1989, 25 other study plans were undergoing review by the DOE. 
In addition to the development of study plans, prototype testing related to various site programs continued. Prototype testing is used primarily to develop testing methods, equipment, and procedures in preparation for the start of new activities. For example, as discussed in Section 2.1.3, prototype drilling and coring has been performed in order to gain experience with the selected drilling technology before its use in obtaining data. Prototype testing does not produce data that can be used in a license application.

Specific progress made during the reporting period in several of the site programs is discussed in the sections that follow. During the reporting periods, more progress was made in several of the larger site programs, such as geohydrology and geochemistry, than in some of the other site programs. In addition, not all studies are addressed in the progress report as some studies have not been initiated, while others may not have produced any noteworthy results during the reporting periods.

\subsubsection{Geohydrology (SCP Section 8.3.1.2)}

Study 8.3.1.2.1.1 - Characterization of the meteorology for regional hydrology

An expanded regional precipitation and meteorology network of about 50 stations has been designed to obtain data for several of the future geohydrology and climate studies. As part of this system, an ALERT-type meteorologic monitoring system was installed at the NTS in cooperation with the DOE Weather Service Office in Las Vegas. The system serves as an automatic flood-warning system activated by either rainfall at a precipitation station or runoff at a stream-gaging station. The system also provides the Weather Service Office with NTS weather forecasts and near real-time data and graphics on precipitation, temperature, wind, and lightning.

\section{Study 8.3.1.2.1.2 - Characterization of runoff and streamflow}

Routine operation of the streamflow and precipitation monitoring networks continued. Surface-water runoff monitoring continued at four continuous-recording gages and at ten peak-flow gages. A new continuous-recording streamflow gage was constructed on Beatty Wash, and several new peak-flow gages were added to the monitoring network.

Areas surrounding Yucca Mountain were evaluated to reassess proposed sites for stream gages for the streamflow network. The channel that drains Crater Flat to the Amargosa Valley was evaluated for the feasibility of a stream gage to monitor the surfacewater yield of Crater Flat. This drainage basin also includes runoff from the west-facing slopes of Yucca Mountain, including Solitario Wash.

Monitoring of debris transport continued. Debris flows from Skull Mountain and Jakes Point were evaluated for the year 1984. The Wren Wash area was investigated for evidence of debris flow. Evidence of runoff and sediment transport was found, but both were minor.

\section{Study 8.3.1.2.1.3 - Characterization of the regional ground-water flow system}

Routine operation of the periodically and continuously measured potentiometric-level networks continued throughout the reporting periods. Locations, depths, potentiometric data, lithologic data, and hydrologic analyses for water wells and drillholes within the 
regional ground-water flow system have been compiled for use in potentiometric and flow analyses.

A review of the geophysical surveys planned, or proposed, for specific problem resolution in the regional ground-water flow system was conducted. Of particular importance is the cause of the large hydraulic gradient north of Yucca Mountain. Methods of exploring the gradient, including the possibility of using geostatistics to assess data uncertainty associated with the planned use of piezometers, were evaluated.

A reconnaissance field trip to Fortymile Wash was made to determine (1) potential locations for performing infiltration testing, (2) sites for construction of piezometer-equipped unsaturated-zone monitoring holes, and (3) location of existing infiltration ponds. Neutronlogging holes UZN 85, UZN 91, and UZN 92 were found to be suitable for infiltration testing. No sites for the construction of piezometer-equipped unsaturated-zone holes were found. Existing ponds were all found to be unsuitable for infiltration studies.

\section{Study 8.3.1.2.1.4 - Regional hydrologic system synthesis and modeling}

A workshop was held to discuss alternative causes and preliminary simulations of the large hydraulic gradient beneath northern Yucca Mountain. The possibility of fracture response to local differences in in-situ stress was discussed. However, most of the discussion centered on hydrogeologic controls resulting from stratigraphic, structural, and secondary-alteration features associated with the Timber Mountain-Claim Canyon caldera complex. The characterization and preliminary simulation of the large hydraulic gradient were also discussed at the spring 1989 meeting of the American Geophysical Union (Stinton, 1989; Czarnecki, 1989).

\section{Study 8.3.1.2.2.1 - Characterization of unsaturated-zone infillration}

Monitoring of natural infiltration continued through monthly neutron moisture logging of 74 existing boreholes, and semiannual sampling of gases and water vapor for isotope analyses at borehole USW UZ-1 continued during the reporting periods.

Infiltrometer measurements were made in the Topopah Wash to characterize stream-channel hydraulic characteristics. Laboratory tests were conducted to define the physical characteristics of the channel sediments.

Vegetation and soils mapping was performed as part of the prototype characterization of surface materials and prototype remote-sensing studies. Prototype infiltrometer measurements were made in connection with the mapping work, all of which will be entered as data layers in the Geographic Information System, a data base and graphics system. Laboratory analyses of the hydraulic and physical properties of the soils from the mapped areas were performed in parallel with the mapping and infiltrometer work.

Work continued on modeling the spatial variability of solar radiation over Yucca Mountain using a clear-sky solar radiation model. Half of the expected number of computer simulations and some preliminary geostatistical analyses of this modeled data have been completed. A thorough evaluation of the influence of ridges that block direct beam and circumsolar diffuse radiation was performed. The influence of the ridges had to be specifically evaluated for the atmospheric conditions present at the NTS for the evapotranspiration studies and the regional meteorology studies. 
Study 8.3.1.2.2.2 - Water-movement tracer tests

A suite of core samples were analyzed for chlorine-36 at the University of Rochester's accelerator mass spectrometer. Samples from borehole USW UZ-1 and G-Tunnel indicate high values of chlorine-36 at depth. In G-Tunnel, there is a visible fault near the sample collection points. The relationship between this fault and the high chlorine-36 values will be investigated.

Study 8.3.1.2.2.3 - Characterization of percolation in the unsaturated zone: surface-based study

Prototype imbibition tests on core samples were completed. During the first part of the test, evaporation studies were made to determine how long core samples can be out of the Lexan liner before significant loss of water occurs. Imbibition tests were also conducted in two dry-drilled boreholes in G-Tunnel.

Progress was made in modeling and data processing software for vertical seismic profiling. Progress was made with the program to image reflecting and diffracting surfaces in a variable-velocity medium using reverse time migration. The problem of errors in calculating travel time from the source to every point in the medium has been solved by modifying the program to eliminate refraction. A sample data set was prepared to test the migration program, but, since the sampling interval was inadequate (as is the case for most actual data sets), an interpolation process was designed to resample the data. The modified imaging package was tested on the sample data set with results that were only partially satisfactory. It was observed that some reflections or diffractions from the synthetic model arrive at times close to first arrivals, tending to "smear" the image. The imaging program is being redesigned to remove these events, which should produce sharper images. The imaging package has also been supplied with a new forward travel time module. The module calculates travel time from an arbitrarily located source to any point in the medium and eliminates head-wave travel paths from consideration.

Examination continued of multichannel filtering schemes to separate compressional and shear waves. Multicomponent vertical seismic profiling and cross-hole data sets are being acquired with physical models to test mode separation algorithms. Two approaches to separation are being used: (1) multichannel velocity filtering and data rotation; and (2) multichannel velocity filtering, eigenmatrix analysis, and subsequent data rotation. Only the first approach has been applied to the data thus far, with acceptable results. The second approach, which is more theoretically rigorous, may produce better results.

Study 8.3.1.2.2.4 - Characterization of percolation in the unsaturated zone: exploratory-shaftfacility study

The ESF radial-borehole test described in the SCP (Activity 8.3.1.2.2.4.4) was modified. Modifications included the elimination of the lowermost set of "short" radial boreholes, which were planned at a location just below the lower breakout room of the ESF. This was done because the planned depth of the first exploratory shaft was provisionally decreased pending a risk/benefit analysis for penetration of the Calico Hills unit. In addition, six sets of "long" radial boreholes (100 feet) have been added to the test design to perform gas-phase permeability testing at the midpoints of major hydrogeologic units. To substantially increase the volume of rock tested, the long radial boreholes will be used to conduct air-permeability interference tests with one of the multipurpose boreholes (USW MP-1). 
The design of the projection moire setup was completed. Preliminary experimentation proceeded with well-defined geometrical objects including a flat surface that can be tilted and a cube. The results are currently being analyzed and will help in better defining a standard to assess the sensitivity of the system. Images of the moire fringes were digitized and stored in the computer. Experimentation with various grating densities to assess the resolution limits of the current experimental moire setup was also performed. The computer program that allows the evaluation of the sensitivity of the projection moire system for different configurations was completed. Work also continued in defining and implementing a calibration target for the lower resolution levels.

The straddle-packer system was successfully tested in the field near Superior, Arizona. The system's injection and monitoring strings were placed in separate holes, and saturated gas was injected into the formation at prescribed flow rates. Shut-in tests were performed, with instrument readouts providing acceptable values. Eight constant-flow-rate tests were performed along with four shut-in tests. The air-permeability testing tools, dataacquisition system, gas-saturation unit, and related accessories performed well. Regressions were performed on calibration data to define the relation between the output signal of the pressure transducer and the actual pressure.

Modifications have been completed to the computer program that determines the best estimates of permeability and wellbore storage using a nonlinear regression algorithm called the Levenberg-Marquardt method. The changes allow for output correlation matrix, eigenvalues, and singular values and also provide confidence intervals and standard deviations for permeability and storage.

Dry-coring and optimal-rubble prototype test analysis continued. Thirteen blastingproduced rubble samples were collected in the alcove in G-Tunnel. Uniaxial-compression testing of welded tuff continued. Tests on four nonwelded tuffs and one welded tuff were conducted. Two of the nonwelded-tuff tests are the first of a group of tests to investigate the effects of rubble coring on the chemistry of pore water. Nine uniaxial-compression water samples were collected and sent to the Rocky Mountain Analytical Laboratory for a compression water analysis. A report on prototype triaxial-compression extraction of pore water from unsaturated tuffs (Yang et al., 1988) was published.

Preparations for prototype testing associated with ESF hydrochemistry testing, intact fracture, bulk permeability, radial borehole testing, and perched-water tests were made. These activities included the development of technical methods and procedures, the design and construction of test equipment, and the calibration of instrumentation.

Progress toward developing conceptual and numerical models of flow in the unsaturated fractured tuffs at Yucca Mountain was made. Numerical simulations of fluid flow in unsaturated fractured rock were performed to help evaluate the feasibility of the ESF percolation tests. A computer code was written that accounts for the dependence of both the magnitude and the direction of the principal hydraulic conductivities on the matrix potential. An approach to account for diffusion into the matrix during transient water movement through unsaturated fractured rock was developed and incorporated into the TOUGH computer code for multiphase fluid flow. In addition, a mathematical formulation was developed for computer-based particle tracking with both continuous-flow-path and random-walk approaches; this formulation will be used for site-scale modeling of the unsaturated zone. Numerical studies of the effects of air and liquid-water drilling on moisture conditions in unsaturated fractured rock were published (Bodvarsson et al., 1988). The development of a numerical model for evaluating fluid flow in major faults and fracture zones also began. 
Significant progress was made in developing the Integrated Data Acquisition System (IDAS). The IDAS is a surface-based system for processing data obtained through the testing and monitoring of unsaturated-zone boreholes. Design, coding, and field testing of prototype IDAS software for unsaturated-zone borehole testing and monitoring were completed. Software for IDAS microwave communications and system maintenance was tested. Work continued on developing the overall IDAS system manual, as well as the design, construction, and testing of the prototype IDAS instrument shelter. Construction of the IDAS archiving center was completed. Prototype IDAS hardware was installed at boreholes USW UZ-1 and UE-25 UZ-4, and field testing of the system began.

\section{Study 8.3.1.2.3.1 - Characterization of the site saturated-zone ground-water flow system}

Ongoing monitoring of water-table levels in the vicinity of Yucca Mountain was performed through the use of continuous transducer-recorder systems in 23 zones of 14 wells and by periodic manual measurements in 11 other wells. Satellite data- collection platforms were installed on selected wells at Yucca Mountain to provide early warning of equipment failure or sudden water-level fluctuations. Automated first-level filtering of all transducer output through 1988 was completed. A systematic evaluation of transducer signals was completed through 1988 for all wells in the continuous water-level network to determine which periods of record were reliable and to identify and analyze apparent anomalous water-level fluctuations. A report was published on water levels in periodically measured wells from 1981 through 1987 (Robison et al., 1988).

Data on magnetic storms were collected to determine whether large-scale anomalies in the continuous water-level network might correlate with such storms. A prototype mechanical device to detect anomalous water-level rises was designed and constructed.

Barometric pressure data from Brown's Room in Devil's Hole, Death Valley National Monument, were acquired and analyzed for use in evaluating water-level fluctuations in the Paleozoic aquifer system.

An analysis of previously completed hydraulic-stress tests in the saturated fractured tuffs of the C-hole complex continued. Equipment and technologies for conducting cross-hole hydrologic and tracer tests at the $\mathrm{C}$-hole complex were evaluated, and a preliminary conceptual design of a multiple-packer well-testing system was completed.

Three zones in wells UE-25c\#2 and UE-25c\#3 were equipped with electronic pressure transducers and data-acquisition systems to initiate the collection of hourly waterlevel data. These data are needed to establish background hydraulic conditions and to document high-frequency water-level fluctuations prior to the conduct of additional hydraulic-stress tests in the C-hole complex.

\section{Study 8.3.1.2.3.2 - Characterization of the saturated-zone hydrology}

Meetings were held with technical representatives of two foreign organizations involved in repository programs--Atomic Energy Canada, Limited (AECL), and the Swedish Nuclear Fuel Supply Company. During the meetings, an examination of hydrochemical experimental and mobile laboratory facilities was conducted to assist in development of the technical strategy for characterizing saturated-zone hydrochemistry at Yucca Mountain. A particular focus of the meetings was to initiate discussions pertinent to the possible application of the Swedish in-situ hydrochemical-sensor system for studies at Yucca Mountain. The planned 
acquisition of the Swedish downhole hydrochemical tool necessitates a demonstration of tool performance at temperatures and pressures expected at and in the vicinity of Yucca Mountain.

Study 8.3.1.2.3.3 - Saturated-zone hydrologic system synthesis and modeling

Efforts were made to make the finite-element flow and transport code TRINET run more efficiently. A conjugate gradient solver for symmetric matrices that saves the decomposition steps for later use was tested successfully in TRINET, and the time-dependent boundary condition option was incorporated. The TRINET user's manual continued to be revised as the code was modified. Work began on developing an equivalent discontinuum model to simulate saturated fracture flow at the scale of well tests and at the site scale. Statistical analysis of fracture-orientation data obtained from the C-holes was performed as an aid to conceptual-model development.

\subsubsection{Geochemistry (SCP Section 8.3.1.3)}

\section{Study 8.3.1.3.2.1 - Mineralogy, petrology, and chemistry of transport pathways}

An operator variance test for modal point counts of the Topopah Spring Member of the Paintbrush Tuff was conducted (Moore et al., 1989). Independent point counts were made by two petrographers for samples representing the lower nonlithophysal zone, the lower lithophysal zone, the middle nonlithophysal zone, and the upper lithophysal zones of the Topopah Spring Member. The point counts included analysis of cryptocrystalline, spherulitic, and granophyric devitrification textures as well as phenocrysts. The results of the operator variance tests indicated that operator differences significantly affect the results of petrographic modal analysis of thin sections. However, the individual petrographers were able to reproduce point count results within random error.

Core from well J-13 was selected, sampled, examined, and analyzed. Comparisons of J-13 core with core from boreholes USW G-4, USW G-1, and UE-25a\#1 suggest that the intervals where heulandite is found in fractures in nonzeolitic rock have not been below the water table since the formation of the heulandite (Carlos, 1989). Manganese oxide minerals in fractures in the Crater Flat Tuff from borehole USW G-4 were also studied. The dehydration properties of the basal vitrophyre of the Topopah Spring Member were studied by dynamic thermogravimetric analysis and long-term isothermal experiments.

The reduction of X-ray-diffraction data was completed for the exploratory-shaft prototype mineralogy-petrology test. The collection of data by neutron-activation analysis continued, and analysis of the collected samples by $\mathrm{X}$-ray fluorescence was initiated. The initial results of the X-ray-fluorescence analyses support the X-ray-diffraction data in showing that centimeter-scale variability may be as significant as larger scale stratigraphic variations in the devitrified rhyolitic Topopah Spring Member (Broxton, 1989).

The prototype test to develop procedures for collecting bulk-rock samples in the exploratory shaft focused on laboratory studies of outcrop samples collected from the west face of Yucca Mountain. Matrix variability of the devitrified Topopah Spring Member was studied by a combination of petrographic, X-ray-diffraction, X-ray-fluorescence, and automated-neutron-activation analysis methods. Collection of textural, mineralogic, and chemical data was completed, and the information was submitted for a statistical analysis of sample-size effects and vertical and lateral variability effects within the Topopah Spring Member. 
Preliminary work began to identify trace minerals that could be important in retarding the movement of radionuclides, particularly actinides, in ground water. To characterize the minerals of high specific gravity in the Topopah Spring Member, a heavyliquid mineral separation was made. Constituents of the high-density fraction included biotite, hematite, allanite, and an isometric oxide (possibly maghemite). Additional studies of iron- and manganese-bearing trace minerals were made using image analysis of backscatter electron intensities generated by a scanning electron microscope.

To investigate the interactions of radionuclides and tuff at Yucca Mountain, quantitative X-ray-diffraction analyses of samples used for batch sorption experiments were completed (Chipera and Bish 1989a). The occurrence and distribution of erionite at Yucca Mountain were also evaluated (Chipera and Bish, 1989b).

Manganese-oxide minerals from fractures in the Crater Flat tuff in USW G-4 were with an optical microscope, a scanning electron microscope, an electron microprobe, and $\mathrm{X}$-ray powder diffraction to determine their distribution, mineralogy, and chemistry.

\section{Study 8.3.1.3.2.2 - History of mineralogic and gcochemical alteration at Yucca Mountain}

The origin of authigenic mineral deposits and breccias along the Bow Ridge and other faults in the vicinity of Yucca Mountain was studied. Samples from Trench 14 have been analyzed by scanning-electron-microscope image analysis and by electron microprobe to determine the major modes of calcium, silicon, and magnesium elemental distributions resulting from authigenic mineral growth in the hydrogenic deposits. These three elements are most important because they are the major constituents in the only authigenic minerals (i.e., calcite, opal, and sepiolite) identified in abundance within Trench 14. Dosimeters were placed in bedrock at Trench 14 and at Busted Butte to measure natural radiation levels for use in age dating based on electron-spin-resonance data. The electron-spin-resonance dating technique is being used to determine the timing of secondary mineral formation at these sites.

Work was initiated for the radiometric dating of zeolites, clays, and authigenic feldspars at Yucca Mountain by the potassium/argon method. A number of illite samples have already been dated by this technique. In this new study, dates will be compared with those from clays and illites from the same or equivalent samples when possible.

$\mathrm{X}$-ray-diffraction heating experiments were conducted with commercial samples of chabazite and heulandite as part of a study to characterize the thermal properties of these minerals. Enhanced data reduction was made possible by the use of Rietveld refinement techniques so that the loss of water from particular structural sites during heating could be characterized.

\section{Study 8.3.1.3.3.3 - Conceptual model of mineral evolution}

A preliminary conceptual model of mineral evolution was developed. The conceptual model stresses the factors that control mineral transformations and the time scale on which the transformations are likely to take place. Work was also conducted on the smectiteto-illite transition. The interpretation of data to date does not demonstrate whether the transformation is controlled by chemical equilibrium or is an irreversible process. The effects of temperature, activity of aqueous silica, and activity of water on possible intermediate illite-to-smectite compositions were examined. 


\section{Study 8.3.1.3.4.1 - Batch sorption studies}

Batch sorption experiments of nickel on tuff under various water compositions were completed. The waters used in the experiments were from wells $\mathrm{J}-13, \mathrm{H}-3$, and UE-25p\#1, with J-13 water used as a reference. The H-3 and UE-25p\#1 waters represent extremes in water composition found at Yucca Mountain, each showing higher cation concentrations than J-13 water. Mass-spectrometry analysis of the sorption behavior of americium in Yucca Mountain tuffs continued.

Sorption measurements were initiated to determine the sorption ratios for strontium, cesium, and barium at different solution-to-solid ratios, using a tuff sample as the solid. The study of the sorption of neptunium on goethite was also started. The work on goethite has been separated into two related tasks. One concerns the characterization, by extended $\mathrm{X}$-ray-absorption fine-structure analysis, of the species of neptunium that are sorbed on pure goethite. The second task involves a more detailed experimental and theoretical investigation of the behavior of neptunium on the goethite surface. The current sorption-data base was used to develop models using the linear, Langmuir, Freundlich, and modified Freundlich isotherm methods. Development of surface-complexation modeling strategies in support of the single-mineral-sorption work started.

Batch sorption experiments with neptunium, americium, and technetium on purecrushed minerals were initiated. The minerals included synthetic and natural calcite, hematite, goethite, cryptomelane, romanechite, montmorillonite, and clinoptilolite. The initial experiments showed strong adsorption of neptunium onto iron and iron-manganese oxides and oxyhydroxides.

A numerical method of regularization has been used to effect the deconvolution of isotherms, obtained from the literature, describing the exchange of lithium, potassium, and rubidium into the synthetic faujasites $\mathrm{NaX}$ and $\mathrm{NaY}$ (Triay and Rundberg, 1989a). The obtained selectivity-coefficient distributions fit the univalent isotherms used for deconvolution.

Triay and Rundberg (1989b) also used this method of deconvolution to determine the site-specific selectivity coefficients for divalent and trivalent exchange in relatively rigid exchangers. The technique involved the measurement of ion-exchange isotherms and the application of the numerical approach of regularization to effect deconvolution. The method has been designed and extensively tested with computer-generated isotherms. The results of these numerical studies are being evaluated to determine whether this approach can successfully recover selectivity-coefficient distributions from divalent and trivalent isotherms. If a careful accounting of the exchanging cations is maintained, this method could be applied to systems undergoing ion exchange.

\section{Study 8.3.1.3.4.2 - Biological sorption and transport}

The study of biological sorption and transport continued. A major mechanism by which microorganisms can influence the mobility of actinide elements is chelation. Iron $\left(\mathrm{Fe}^{3+}\right)$ and plutonium $\left(\mathrm{Pu}^{4+}\right)$ are similar in their charge-to-ionic radius ratio. $\mathrm{Pu}^{4+}$ can be chelated by the $\mathrm{Fe}^{3+}$ siderophores (microbial iron-chelating compounds). Investigation of the chelation of $\mathrm{Pu}^{4+}$ by microbially produced siderophores will continue. Siderophorepurification techniques were developed. Work is continuing on determining the effect of microorganisms on the rate of colloidal agglomeration. 
Study 8.3.1.3.5.1 - Dissolved-species concentration limits

Ongoing studies of radionuclide retardation by precipitation processes continued. Efforts to study the properties of the plutonium $\left(\mathrm{Pu}^{4+}\right)$ colloid have focused on three main areas: (1) chemical oxidation of the colloid with cerium $\left(\mathrm{Ce}^{4+}\right)$, (2) electrochemical reduction and oxidation by voltammetry, and (3) size determination by autocorrelated photon spectrometry. Results to date provide further evidence that colloidal $\mathrm{Pu}^{4+}$ is structurally similar to plutonium dioxide and is electrochemically reactive.

Solubility experiments for neptunium, plutonium, and americium in well $\mathrm{J}-13$ ground water at $25^{\circ} \mathrm{C}$ and with $\mathrm{pH}$ values of $5.9,7.0$, and 8.5 were completed. In addition, a summary of work conducted from October 1, 1985, to September 30,1987, on the solubilities of neptunium, plutonium, and americium in well $\mathrm{J}-13$ ground water at three

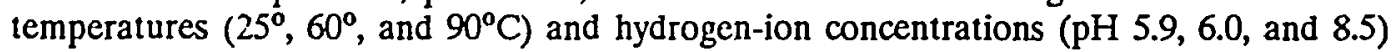
was issued (Nitshe et al., 1989). The solubilities were studied from oversaturation. The neptunium solubility decreased with increasing temperature and with increasing $\mathrm{pH}$. The soluble neptunium did not change oxidation state at steady state. Plutonium concentrations decreased with increasing temperature and showed no trend with $\mathrm{pH} . \mathrm{Pu}(\mathrm{V})$ and $\mathrm{Pu}(\mathrm{VI})$ were the dominant oxidation states in the supernatant solution; as the amount of $\mathrm{Pu}(\mathrm{V})$ increased with $\mathrm{pH}, \mathrm{Pu}(\mathrm{VI})$ decreased. Steady-state concentrations for the americium experiments at $60^{\circ} \mathrm{C}$ were not obtained within 5 months. The high specific alpha activity of the americium solution probably caused this problem. The americium supernatants did not change oxidation state.

\section{Study 8.3.1.3.6.1 - Dynamic transport column experiments}

The behavior of three colloids was investigated during flow through a saturated column of densely welded fractured tuff from the Topopah Spring Member to study the ability of the tuff to act as a natural filter for particulate matter. Plutonium colloids prepared under various conditions were characterized by autocorrelated photon spectrometry.

Diffusion experiments in rock beakers were initiated. Two different solutions, one containing strontium, cesium, and barium and the other containing strontium, cesium, barium, americium, and neptunium, were placed in a number of rock beakers. The solutions in the rock beakers will be sampled periodically for 2 years.

Twenty-millimeter columns made of polycarbonate have been fabricated to study the transport of radionuclides in pure crushed minerals, including synthetic calcite and hematite; natural cryptomelane; and purified clinoptilolite, calcite, and romanechite. The ability of the polycarbonate columns loaded with these pure minerals to prevent leakage was studied.

The ability of Yucca Mountain tuff to act as a natural filter for particulate matter continues to be studied using Calico Hills and Topopah solid rock columns. Two columns each of Calico Hills tuff and Topopah tuff were used. The elution of 0.09 -micrometer fluorescent colloids through the columns continued, and the amount of colloid eluting was analyzed using quantitative fluorimetric analysis. 
Study 8.3.1.3.7.1 - Retardation sensitivity analysis

The COVE2a benchmarking calculations were completed with the computer code TRACR3D. The COVE2a activity consisted of 12 isothermal one-dimensional problems, 6 steady and 6 nonsteady cases, of flow through a vertical column of 5 fractured geologic layers. Other work included adding a nonvertical gravity vector to the TRACR3D code to facilitate the modeling of tilted geologic layers and horizontal and tilted boreholes.

Code development work was completed on computer codes FEHMN (Finite Element Heat-Mass) and FEHMSN (Finite Element Heat-Mass-Stress). For FEHMN, unsaturated zone flow and heat transfer capabilities were added and verified; a multipletracer capability and a reactive-tracer capability were added; a zoning capability that allows for irregularly shaped zones within the grid was added; and an adaptive solution strategy for multiple degree of freedom problems was developed. For FEHMSN, the fully coupled two-dimensional stress and mass-transport module was implemented and compared with analytic solutions of hydraulic fracturing. The verification plan was written for FEHMN, and many problems have been run. A verification structure was set up in FEHMN for comparing the numerical solutions with analytic solutions.

A two-dimensional version of the colloid transport code (CTCN) was developed, and most of the modules have been finished. The code was tested against analytic solutions to problems and against solutions obtained by other similar codes. Verification of the method of lines code, which is the solution routine in CTCN, was implemented properly.

An updated conceptual model of the site was developed. The model includes a three-dimensional representation of the tilted stratigraphic beds with offset along the Ghost Dance Fault zone and spatially distributed sorption coefficients that are functions of mineral assemblage. Results from sensitivity studies based on this model will be used to guide the geochemical site characterization of Yucca Mountain. The model will be updated to integrate new data as they become available from mineralogy and petrology work, sorption studies, radionuclide-solubility studies, and ground-water chemistry studies.

A nonvertical-gravity-vector option: was added to the transport model TRACRN. This option simplifies the grid setup for systems with tilted beds or nonvertical boreholes. A double-precision version of TRACRN that will run on 32-bit machines was also developed. This version was tested and has become the baseline version of the code. A Cray version is now being generated by transforming the baseline version with an editing file. The code is under configuration management.

\subsubsection{Rock characteristics (SCP Section 8.3.1.4)}

\section{Activity 8.3.1.4.1.2 - Integration of geophysical activities}

A review of past geophysical work performed and the integration and prioritization of new geophysical work to be conducted as part of site characterization were initiated.

Study 8.3.1.4.2.1 - Characterization of the vertical and lateral distribution of stratigraphic units within the site area

An examination of bulk porosity above the static water level in lithophysal zones calculated with borehole gravity and gamma-gamma density log data from drillholes in densely welded tuff at Yucca Mountain was completed. 
The Campbell Pacific Nuclear DR-501 neutron moisture and gamma density gage was operated in both wet- and dry-drilled boreholes at G-Tunnel. The information obtained on the rock properties will help to determine the usefulness of this combination tool for borehole geophysical logging at Yucca Mountain. Work continued on improving density log readings in air-filled boreholes. Information on geophysical logs and core measurements from 40 boreholes at Yucca Mountain has been compiled. Evaluation of rock paleomagnetic data for determining the magnetic properties of Tiva Canyon Tuff was initiated.

\section{Study 8.3.1.4.2.2 - Characterization of the structural features within the site area}

Prototype studies of shaft-wall mapping techniques for the investigations of the geologic framework of the Yucca Mountain site continued. These studies include equipment development and improvements in photogrammetric methods and the use of analytical plotters. Results indicate the potential for not only greater speed in mapping shaft and drift walls but also enhanced quantitative analysis of geologic features before and after the loss of rock exposures because of shaft lining.

The test fixture for the exploratory-shaft mapping has been completed. The fixture, with the photogrammetry control targets in place, was photographed, and the photogrammetry laboratory has begun analyzing the templates. The photograph templates (stereophotograph strips printed on 8 - by 10 -inch film positives for use in the analytical plotter) will be used to test shaft photogrammetry procedures.

\subsubsection{Climate (SCP Section 8.3.1.5)}

Study 8.3.1.5.1.2 - Paleoclimate study: lake, playa, marsh

Over 100 references pertaining to modern or fossil mollusks (terrestrial and aquatic) from southern Nevada have been assembled. Modern biogeographic data for taxa known to have lived in this region during the isotopic stage are currently being compiled to provide baseline data for paleohydrologic interpretations.

Investigations of modern ostracode taxonomy and distributions continued. Work is also continuing on the development and updating of data bases concerned with ostracode taxonomy and ecology and on the methods to be used in chryophyte-cyst sample preparations. An evaluation of the paleoenvironmental potential of diatoms preserved in spring deposits was initiated.

\section{Study 8.3.1.5.1.3 - Climate implications of terrestrial paleoecology}

Work continued on the comparison of several different methods of palynological-data processing. Bibliographic investigations were conducted on palynological extraction methods not previously considered and on late Quaternary Pacific sea-surface temperatures.

Collections of modern botanical-type materials were catalogued, and bibliographic research was conducted on modern plant distributions. Development of a reference data base on soil and plant relationships and on the hydrologic role of vegetation in central and southern Nevada was initiated. 
Ongoing monitoring of the southern Great Basin dust-trap network continued. This monitoring allows an evaluation of the significance of airborne-dust contributions to the development of soils in the Yucca Mountain region and is part of soil-modeling activities designed to provide information on the paleoenvironment of the region.

Related prototype activities included experimenting with techniques to establish the ages of soils and other young surficial deposits. The techniques investigated included uranium-series dating of carbonate root casts, thermoluminescence dating, and the use of cation ratios from rock varnish for age determinations.

\section{Study 8.3.1.5.1.6 - Characterization of the future regional climate and environments}

In preparation for characterizing the future regional climate, a feasibility study was completed by the National Center for Atmospheric Research. This study focused on the feasibility of using an existing global climate model to drive a high- resolution regional climate model of the southern Great Basin extending over the next 100,000 years.

\section{Study 8.3.1.5.2.1 - Characterization of the Quaternary Regional Hydrology}

Monitoring of hydrologic conditions at the Kawich Creek and the Stewart Creek analog recharge basins in central Nevada continued. Study sites were upgraded through the installation of additional meteorological stations, flumes on stream channels, and satellite communications systems.

Prototype testing included the evaluation of techniques for the collection and analysis of terrestrial and aquatic organisms to obtain information about hydrologic conditions in past discharge areas. Ostracod data from samples collected in Kansas, Colorado, and New Mexico are being organized as a prototype test activity within paleohydrology. Efforts to improve the methods to be used in chryophyte-cyst sample preparations and work on creating a macrofossil data base for use with other paleoclimate indicators continued. Literature searches and modern mollusk biogeographic data are being organized to provide baseline data for paleohydrologic interpretations.

Biological and hydrologic data were collected from the analog recharge sites. Preliminary studies began at the arid-zone monsoonal analog research site near Tucson, Arizona. These studies surveyed atmospheric conditions to determine the type of instrumentation needed for collecting data to support the soil-chemistry/ climate model. A reconnaissance of the Rattlesnake Ridge area along Rainier Mesa was conducted, and two potential areas for weather monitoring stations were located. These areas will extend the range of climates being investigated by the analog recharge activity to a climate that is only slightly wetter than that existing at Yucca Mountain today.

Strontium-isotope analyses and X-ray-diffraction-trace element analyses of carbonates and spring waters from around Yucca Mountain continued as part of scoping studies. Experiments on the use of mass spectrometry for uranium-series dating and the development of a carbonate-rock standard for uranium-series dating were conducted. Uranium-series analyses of calcite vein deposits were performed. 


\subsubsection{Postclosure tectonics (SCP Section 8.3.1.8)}

\section{Study 8.3.1.8.5.1 - Characterization of volcanic features}

A preliminary geologic map of the Lathrop Wells volcanic center was completed (Crowe et al., 1988). Current interpretations of data from field, paleomagnetic, geomorphic, soils, and rock-varnish studies indicate that the eruptive events at the Lathrop Wells volcanic center occurred as follows. First, a northwest-trending fissure zone, marked by local accumulations of scoria and spatter, developed east of the main volcanic cone. Smallvolume lava flows erupted from several localities along the fissure zone. Numerous small scoria cones formed at the south end of the main scoria cone. The major part of the main scoria cone formed during the initial stages of volcanic activity. Second, one and possibly two small fissure zones, marked by scoria mounds, formed at the northern and northeastern flanks of the main scoria cone. These fissure zones vented small-volume block lava flows from numerous localities along the fissure zone. Finally, one or more small-volume (approximately 10,000 cubic meters) scoria eruptions occurred from the summit of the main scoria cone of the Lathrop Wells center. These eruptions draped the cone summit, cone slopes, and immediate adjacent area with thin scoria-fall deposits. The geomorphic and soil characteristics of this last eruption suggest that it could have occurred as recently as the late Pleistocene or Holocene Epoch.

Additional sampling of surface core from volcanic centers was completed. Sampling sites included Lathrop Wells center, Little Black Peak and Hidden Cone of the Sleeping Butte centers, and Red Cone and Black Cone of the $1.2 \mathrm{Ma}$ volcanic centers. Potassiumargon age determinations were completed for 11 sample sites in the Yucca Mountain region, including the 1.2 Ma volcanic centers of Crater Flat and the $3.7 \mathrm{Ma}$ centers of southeast Crater Flat and Buckboard Mesa.

A possible new tephra-fall unit was recognized at the Lathrop Wells volcanic center. This unit was inferred to represent the youngest eruption from the center. Five samples from the Lathrop Wells volcanic center and three from the " $\mathrm{A}$ " Cone of the Cima volcanic center were collected for thermoluminesence dating. Field evaluation of rhyolite domes dated at approximately $2.9 \mathrm{Ma}$ was completed in the Mount Jackson area, located 100 kilometers northwest of the Yucca Mountain site. These rhyolite domes represent the youngest silicic volcanism in the region.

Developmental work continued on the noble gas mass spectrometer system. System development was sufficiently complete to begin analysis of the first basalt samples. Mineral separation techniques are being optimized to separate coarse-fraction olivine grains to minimize loss of helium by diffusion. The first analytical runs for uranium-thorium disequilibrium measurements of three samples from volcanic units of the Lathrop Wells volcanic center have been completed. The analyses were successful; however, the mineral separations for each sample did not have sufficient variance in uranium and thorium contents to establish an isochron. Work continued to develop more efficient separation techniques using magnetic and heavy-liquid separations.

Prototype work included the development of analytical techniques to establish the age of Quaternary volcanic units in the Yucca Mountain region. The primary techniques include uranium-thorium disequilibrium measurements by solid-source-mass spectrometry and the measurements of surface exposure ages by the helium-isotope dating technique. Geochemical techniques for identifying the sources and number of ash horizons exposed in fault trenches were also evaluated. Proton-probe analysis of trace elements at the partsper-million level have been completed for individual ash grains from the Lathhrop Wells volcanic center. 
Rock-varnish studies were performed. The studies involve rock-varnish dating of geomorphic surfaces on and around Yucca Mountain (including alluvial fans, fluvial terraces, hillslope deposits, lava flows, and pediments) to determine the time of surface stabilization (since stable surfaces formed on lava flows) and to constrain the timing of geologic events that have formed, deformed, or modified these surfaces. Rock-varnish geochemistry studies to determine the chemical basis and processes operative in rock-varnish formation and in cation depletion within rock varnish through time continued.

\subsubsection{Thermal and mechanical rock properties (SCP Section 8.3.1.15)}

As part of the prototype activities conducted to support studies that examine spatial distribution of thermal and mechanical properties, a high-pressure flatjack test was completed in G-Tunnel. The experiment used displacement measuring instruments, and the results can be used to evaluate jointed block models as well as flatjack designs. A high-pressure flatjack was placed in a 1-meter-deep slot cut in the rib of the demonstration drift. Linear variable displacement transducers, cable-actuated wire displacement gages, and sliding micrometers were installed across the slot at various gage lengths. Displacement measurements were also made across the drift to measure the "heave" of the rock on either side of the slot as the flatjack pressure was increased. Acoustic emission sensors were installed to monitor fracturing events within the rock as pressure was increased. Flatjack pressure was increased to $2,500 \mathrm{psi}$ and cycled down to 0 psi. Pressure was subsequently increased to about $4,500 \mathrm{psi}$, at which point a large piece of rock on the right side of the slot failed, exposing a portion of the flatjack. The part of the flatjack that was exposed inflated to about 2 inches, but did not fail. Pressure was reduced slowly to 0 , and the experiment was concluded. The 4,500-psi pressure attained is the highest pressure achieved in any of the flatjack or pressurized slot tests to date.

A new technique involving drilling a horizontal starter hole 4 feet long with an 8-inch diameter was employed to cut a 1-meter-deep slot in the rib of the demonstration drift in densely welded tuff in G-Tunnel. The starter hole allows a uniform number of cutters under constant pressure to bear on the cutting surface. This is the first successful slot cut in the densely welded tuff using a hydraulic control system.

The new modular hydraulic chain saw, which will eventually be capable of cutting slots 1 and 2 meters deep, was operated to determine the effectiveness of the design and what alterations, if any, must be made. The design of the bar-chain interface must be evaluated to minimize friction between these two components. The problems encountered with the chain and bar may impact the conducting of the rock-mass-response experiment and other experiments in G-Tunnel.

Plans were developed and implemented to expand the G-Tunnel underground facility to make more space in welded tuff available for prototype testing. Mining of two new drifts totaling about 150 fect in length was initiated. One drift will be dedicated to the prototype thermal stress test, and the other will be used in a vertically oriented engineered-barrier test.

\section{Study 8.3.1.15.1.1 - Laboratory thermal properties}

Data on the density and porosity of tuffs in the unsaturated zone at Yucca Mountain were compiled. Calculations of heat capacities for tuffaceous units from the unsaturated zone at Yucca Mountain have been completed. Data analyses used to obtain some of the 
recommended Reference Information Base values for thermal conductivity were completed. A report on thermal data (Sass et al., 1988) from earlier studies was published.

Study 8.3.1.15.1.3 - Laboratory determination of the mechanical properties of intact rock

The relevance of partial saturation to the mechanical properties of tuff was evaluated (Nimick and Peters, 1989). A comparison of two methods of determining tensile strength was also performed.

\section{Study 8.3.1.15.1.4 - Laboralory determination of the mechanical properties of fractures}

In preparation for the characterization of natural fracture surfaces, a laboratory profilometer was fabricated and tested. A preliminary investigation of two techniques for studying the mechanical properties of fractures was also initiated. The study compares rotary-shear and triaxial-compression techniques.

\section{Study 8.3.1.15.1.5 - Excavation investigations}

Pretest analyses supporting excavation-investigation experiments for the ESF (shaft convergence, demonstration breakout rooms, and sequential drift mining) were completed (Costin and Bauer, 1989). These analyses provide guidance to experiment planners regarding expected displacements and stresses near the experimental drifts so that selection and placement of instrumentation can be optimized.

\section{Study 8.3.1.15.1.6 - In-situ thermomechanical properties}

Pretest analyses for in-situ thermomechanical experiments planned to be conducted in the ESF (canister-scale heater, thermal stress, and heated room) were completed (Bauer et al., 1989). These analyses provide guidance to experiment planners regarding expected temperatures, displacements, and stresses. The analyses will assist in the correct selection and placement of instrumentation.

\section{Study 8.3.1.15.2.1 - Characterization of the site ambient stress conditions}

Compressive-strength testing of grout specimens from the U.S. Bureau of Reclamation borehole-pressure-gage construction and grout from the Bureau of Mines borehole-pressurecell construction was completed. The modulus of elasticity and Poisson's ratio will be used for comparison with the welded-tuff values where the gages will be placed.

Laboratory testing and calibration of the NX (76-millimeter size) borehole dilatometer was completed successfully, and initial prototype field testing of the dilatometer in G-Tunnel was successfully completed. Preliminary interpretation of the data indicates that the rock modulus measurements are sensitive to joints, faults, and probably differences in lithology. 


\subsubsection{Preclosure tectonics (SCP Section 8.3.1.17)}

Study 8.3.1.17.1 - Relevant earthquake sources

Compilation of existing fault and seismicity data for the NTS area continued. An analysis of the regional termination and segmentation of Quaternary fault belts in the Great Basin, Nevada and Utah, was completed (Thenhaus and Barnhard, 1989).

Study 8.3.1.17.3.3 - Ground motion from regional earthquakes and underground nuclear explosions

Ongoing characterization of the effects of underground nuclear explosions at the NTS and seismic-wave-transmission modeling efforts to develop the capability of predicting amplitudes and acceleration from underground nuclear explosions continued.

\section{Study 8.3.1.17.4.1 - Historical and current seismicity}

Ongoing operation of the Southern Great Basin seismographic network continued. Work continued on the upgrading of the seismic network covering Yucca Mountain and vicinity. A portable array of seismometers was deployed near the Hoover Dam to help understand how seismicity in that area relates to Yucca Mountain. The automatic clock turn-on system for the SGE-III seismographs was successfully tested. The system adds significantly to the seismic-monitoring capability and to the quality of the data that can be collected. In addition, a level line across the Yucca Mountain site was rerun.

\section{Study 8.3.1.17.4.2 - Location and recency of faulting near prospective surface facilities}

Five potential sites for surface-disturbance studies in the Midway Valley (possible trench and test pit locations) have been identified. Archaeological and environmental-compliance reviews for those sites were completed.

Prototype work included the evaluation of various methods for dating Quaternary materials so that reliable studies of fault offset and recurrence intervals can be conducted during site charas "rization. The use of photogrammetric methods and analytical plotters as an aid to rapid and accurate trench mapping was also tested.

Study 8.3.1.17.4.3 - Quaternary faulting within 100 kilometers of Yucca Mountain, including the Walker Lane

Interpretation of the geophysical setting of Yucca Mountain continued. Several newly published or preprinted manuscripts were consulted regarding the physical properties of crustal rocks that produce seismic reflections. In particular, there are clear cases where seismic reflections do not come from layer boundaries, but from metamorphic layering within deep rock bodies of a nearly uniform composition. The significance of this information relative to seismic data in the Yucca Mountain area is being documented.

Seismic profiles in Crater Flat and over Yucca Mountain were reviewed to determine whether seismic-reflection profiles should be conducted in these areas. Aspects of the interpretations that were examined include the thickness of alluvial and other lowvelocity deposits, thickness of volcanic cover, and distance of seismic-energy propagation for different shot points. 
Four maps with a scale of $1: 100,000$ were revised. The maps are for the following Quaternary faults and lineaments: Goldfield/Benton, Last Chance Range, Beatty, and Death Valley Junction. Synthesis of data on Quaternary deposits for the Beatty 1:100,000 quadrangle and a revision of the manuscript for the geologic map of the NTS continued.

A report (Reheis and Noller, 1989) on Quaternary faulting in the southern Walker Lane was published. The application of the morphology and genesis of desert soils to Quaternary studies was evaluated (Reheis, 1989).

Using preexisting data sets, map-controlled and optically corrected synthetic-aperture radar mosaics have been compiled as test products at a scale of 1:250,000 for the Death Valley, Goldfield, and Las Vegas quadrangles. Most of the Caliente quadrangle is also available in flight-strip format to avoid the positive terminal area in its southwestern part. High-gloss positive prints of these radar mosaics are sharp, clear, and well-suited for synoptic lineament or fracture-pattern analyses.

\section{Study 8.3.1.17.4.5 - Detachment faults at or proximal to Yucca Mountain}

Work on the potassium-argon dating of samples from the northwest Spring Mountains and faulting in the Point of Rocks area continued. A report (Scott, 1989) on extensionaldetachment-fault systems in southern Nevada was published.

\section{Study 8.3.1.17.4.6 - Quaternary faulting within the site area}

Four potential trench sites near Yucca Mountain were staked and flagged. Digitizing of existing fault data at Yucca Mountain and programming of translation software for trench mapping continued, as did fission- rack work on air-fall tephra sediments. Compilation of the geologic map for the Beatty 30 - by 60 -inch sheet continued. A geologic map of the surficial deposits of the Topopah Spring quadrangle was completed (Swadley and Hoover, 1989).

Experiments on purifying desert carbonates for uranium-series dating were conducted. Work also continued on software for uranium-series and uranium-trend dating and background activity measurements using alpha detectors. It is planned to test the uranium-trend dating method in a climate similar to that of Yucca Mountain (i.e., the Cima volcanic field in California).

Study 8.3.1.17.4.7 - Subsurface geometry and concealed extensions of Quaternary fauls at Yucca Mountain

Work continued on isostatic gravity and aeromagnetic maps of the NTS and vicinity (scale 1:100,000) and the interpretive text to accompany the Las Vegas $1^{\circ}$ to $2^{\circ}$ gravity map. Data for about 300 gravity stations collected in the Timber Mountain area in 1979 have recently been incorporated into the gravity-data files and the isostatic gravity map of the NTS.

A preliminary aeromagnetic map of the NTS and vicinity (Kirchoff-Stein et al., 1989) was completed. The Las Vegas sheet of the aeromagnetic map of Nevada was completed (Saltus and Ponce, 1989). A compilation of aeromagnetic data for the Beatty 1:100,000 quadrangle began. Work continued on the interpretative text to accompany the Las Vegas $1^{\circ}$ by $2^{\circ}$ magnetic map. 
Compilation of existing Landsat multispectral scanner digital tapes and limited feasibility testing of processed multispectral scanner digital mosaics (bands $4,5,7$ ) were completed for the following $2^{\circ}$ quadrangles: Las Vegas, Caliente, Goldfield, and Death Valley. In addition, a concatenated mosaic has been prepared as a test product for all four quadrangles.

Furgerson's (1982) one-dimensional magnetotelluric interpretational composite section across the Walker Lane in the vicinity of Lathrop Wells was tested. A twodimensional interpretation approach showed that the one-dimensional composite has a large-scale error in the vicinity of the Amargosa Desert and Syncline Ridge.

Development continued on alternative models for dipole-dipole resistivity in Coyote Wash that show that data are compatible with the geologic interpretation of a conductive fault or fracture zone or with more conductive lithological change in the Pah Canyon Member tuff and bounding beds.

\subsection{REPOSITORY DESIGN}

The repository-design program consists of the activities associated with designing both the surface and the underground portions of the repository. These activities include the development of design criteria as well as design analyses. There are several phases of repository design. The first phase, the conceptual design phase, is completed and documented in the SCP Conceptual Design Report (SNL, 1987) and Chapter 6 of the $\mathrm{SCP}$. The conceptual design provided the basis for the repository design program described in Section 8.3 .2 of the SCP.

The next design phase is the advanced conceptual design. During the advanced conceptual design phase, studies are conducted to develop and refine design criteria and explore design alternatives. After the advanced conceptual design report is completed, the license application design portion of the Title I and Title II design phases will start. During the license application design phase, the design of the items necessary to demonstrate compliance with the design requirements and performance objectives of $10 \mathrm{CFR}$ Part 60 will be developed. Finally, during the final procurement and construction design portion of the Title I and Title II design phases, the final working drawings and specifications for procurement and construction will be developed.

A number of repository-design studies related to seismic design have been completed. These studies include an evaluation of the potential for seismic ground motion at the site of the repository surface facilities (Sanders, 1988; Kiciman and Abrahamson, 1988) and an evaluation of the impacts of seismic events on repository waste-handling facilities (Subramanian et al., 1988; Ma and Jardine, 1988). A related site study evaluated the quantity of additional data needed on underground nuclear explosions (Easterling and Hall, 1988).

A preliminary cost-benefit assessment was made of the repository waste-handling facilities to evaluate the options for the seismic-design basis for the advanced conceptual design (Subramanian et al., 1989). An analysis of repository waste-handling operations was conducted to evaluate the operational characteristics of the current conceptual design. Also evaluated were methods for the treatment and disposal of the radioactive waste generated at the site as a result of repository operations (Subramanian and Jardine, 1988) and the potential impacts of abnormal events on waste-handling facilities. 
In the SCP Conceptual Design Report, two waste-handling buildings were proposed as part of the surface facilities because it was assumed that the spent fuel received would be consolidated at the repository. However, the DOE is reevaluating the option of consolidation. An evaluation of the impacts of fuel-rod consolidation on waste-handling facilities at the repository was completed and published (O'Brien, 1989). The results indicate that consolidation offers no advantages for the operation or the underground layout of the repository.

Evaluation of proposed drilling techniques for waste emplacement boreholes continued. Currently, the use of percussion drilling equipment is planned; however, this equipment emits a small amount of lubricating oil into the borehole during drilling. Waste-package studies indicate that oil, even in trace quantities, should not be introduced into the repository. In addition to trying to quantify the amount of oil present, consideration is being given to supporting the development of a proposal for air-turbine drilling equipment.

A proposal for the prototype testing of tunnel-boring machinery conducted at Fran Ridge and alternative layouts for the repository emplacement drifts was prepared. The use of tunnel-boring machinery could have a significant impact on the cost and quality of the mined repository. The layout of the shafts and ramps for use with tunnel boring equipment was also prepared.

Parts 2 and 3 of the first benchmark exercise for thermal and mechanical codes continued. Parts 2 and 3 include analyses of elastic rock mass and jointed rock mass. Documentation of the results of the thermoelastic analyses and the benchmarking exercises for the thermal and mechanical codes are in preparation.

As part of testing to verify drift stability, a study of simulated fractures was initiated. The fractures will be made of refractory brick material to allow the length, geometry, and mechanical properties of the fractures and the mechanical properties of the matrix material to be controlled. These engineered materials will then be loaded through controlled stress and/or displacement paths, and attendant deformations will be measured. The results will provide a means to assess the mechanics, phenomena, and kinetics of the joint systems and thus provide a physical basis for understanding the constitutive behavior and the constitutive models applied to analyze the response. After development of procedures, refined methods will be applied to code validation.

\subsection{SEALS-SYSTEM DESIGN}

For the permanent closure of the repository, the DOE currently plans to seal all shafts, ramps, exploratory boreholes, and emplacement drifts. The overall strategy that guides the design of the seals system is to reduce, to the extent practicable, the potential for creating a preferential pathway for water that may be encountered in the unsaturated zone from coming into contact with emplaced waste and to reduce, to the extent practicable, the potential for radionuclide migration through existing pathways. The seals-system design program includes materials testing, design development, and design analysis.

Since seals generally would not be installed until the underground repository is closed, design and seal testing will take place, for the most part, during the period of repository operations. Current plans for investigations conducted during site characterization are aimed at developing design concepts, evaluating seal materials, and conducting preliminary performance assessments. The activities to be conducted during site characterization are described in Section 8.3.3 of the SCP. 
Thus far, the seals-system design program has focused on analyses necessary to support assessments of the postclosure performance of the exploratory shafts, primarily the analyses related to hydrologic phenomena and convective airflow. The sealing-related requirements of the exploratory shaft facility have been developed for inclusion in the Exploratory Shaft Facility Subsystem Design Requirements Document (DOE, 1989d). Sealing requirements for the repository are still under development.

To contribute to the development of a degradation model for cementitious sealing materials emplaced in a tuffaceous environment, comprehensive evaluations of the chemical compatibility of cementitious materials in a tuffaceous environment were conducted. The geochemical modeling code EQ3/6 was used in these evaluations. Interactions of meteoric and ground water with four modeled, cementitious materials in two tuff compositions were studied at a range of temperatures.

Preliminary results provide information related to the dissolution and chemical alteration of the cementitious material and the alteration of ground-water chemistry. Alteration of the ground-water chemistry leads to the precipitation of material either in the cementitious material or the surrounding tuff. These changes were examined along five specific water-flow paths representative of possible flow paths for water movement in shafts or boreholes. The results of these analyses quantify precipitation and dissolution (per liter of ground water) on a phase-by-phase basis for each of the five flow paths. These phase-specific precipitation and dissolution data will be used to predict changes in the porosity of seal material and, consequently, seal permeability.

Support was provided to the Technical Assessment Review of the geologic and geophysical evidence pertaining to structural geology in the vicinity of the proposed exploratory shaft (see Section 2.1.2). This support included evaluating the implications of sealing the exploratory shafts if they were intersected by a fault zone. Documents that model the movement of water near a fault in the unsaturated zone were reviewed; these documents discuss the amounts of water that could possibly enter the shafts as a result of probable maximum floods.

\subsection{WASTE-PACKAGE DESIGN}

According to the current waste-package reference design, the waste package consists of the waste form and the container in which the waste form is placed. The objective of the waste-package design program, described in Section 8.3.4 of the SCP, is to develop a waste package that is compatible with the characteristics of the emplacement environment. The design of the waste package must be integrated with the performance-assessment program to ensure that the waste package will contribute to meeting the performance objectives for waste containment and controlling the release of radionuclides from the engineered-barrier system.

The waste-package design program includes the development of waste-package design bases, design analysis, container-material testing, the development of a reference design, waste-form testing, and the characterization of the waste-package emplacement environment. Progress made during the reporting period in designing and evaluating the waste package and its host rock environment is discussed in the following sections. 


\subsubsection{Postemplacement near-field environment}

Characterization of chemical and mineralogical changes in the postemplacement environment continued in the form of rock-water interaction experiments at elevated temperatures. The purpose of these experiments is to determine how a steady-state tuff-water system responds to perturbations in fluid composition. Analyses of data from hydrothermal experiments on vitric, vitrophyric, and zeolitic tuff continued, with emphasis on evaluating the composition of solid reaction products and solution chemical behavior. Evaluations of thermodynamic data obtained through literature searches were initiated. These data are needed for simulations with the EQ3/6 geochemical modeling code.

Long-term rock-water interactions were investigated through simulations of reactions in concentrated water from well J-13. The collection and evaluation of published water analyses continued, and the simulation of chemical speciation in the various waters was initiated. To determine how grout, concrete, and other repository materials might affect ground-water chemistry, literature evaluations were started.

Dissolution and precipitation kinetics of mineral phases in the waste package environment are under experimental study. This activity has been expanded to include studies of kaolinite, gibbsite, clinoptilolite, heulandite, and cristobalite over a range of $\mathrm{pH}$ values and temperatures. Characterization of the cristobalite crystal structures in reaction cells continued, as did work on the precipitation of cristobalite from solution.

The first prototype engineered-barrier test system field test continued in the G-Tunnel complex at the NTS. The prototype test monitors rock characteristics, such as temperature and moisture content, near a heater emplaced in partially saturated, welded tuff.

The EQ3/6 geochemical modeling code was used to analyze the effects of oxygen fugacity on the solubility of radionuclides released by the dissolution of spent fuel. This is associated with the examination of the processes involved in the transport of radionuclides after release from the waste form. Evaluation of the aqueous transport of uranium in tuff samples under static conditions (McKeegan et al., 1988) continued. Work continued on the development and implementation of techniques for measuring the transport properties of conservative (nonsorbing) and non-conservative (sorbing or reactive) radionuclide tracers under flowing conditions.

With regard to the development of geochemical speciation and reaction models, work continued at the National Institute of Standards and Technology to improve the accuracy of the existing data base for geochemical modeling. This data base is used in evaluating radionuclide transport in the near-field environment. The existing data was moved into a relational-data-base format, providing controls on data integrity and eliminating the need for hand calculations. This format will be used for automated data analysis in the future. The sensitivity and uncertainty work for the data base was begun, including assessments of data needs and automated sensitivity and uncertainty analyses during the use of the EQ3/6 geochemical code.

As part of the fracture-healing work being conducted, water permeability was measured in seven Topopah Spring tuff samples at constant pressure and over a range of temperatures. Dry gas permeability was also measured (using nitrogen) in fractured tuff under the same conditions as the water-permeability measurements. Conclusions are that (1) fractures heai and water permeability decreases significantly with increased pressure at temperatures up to $150^{\circ} \mathrm{C}$; (2) water is required for the fracture healing; (3) fracture surface condition, such as silica coating, does not affect the fracture healing; (4) fracture surface 
roughness has some effect on the fracture healing; and (5) thermal cycling and thermal gradient have little effect on the fracture healing.

Work continued on determining radionuclide-transport parameters in the nearfield environment. With respect to radionuclide distribution in tuff waters, an effort was made to reduce and interpret data acquired during the previous year in experiments that measured the transport rates of actinides in tuff. Also, an effort to determine radionuclide distribution in tuff cores involved experiments in which transport rates of actinide-bearing solutions in tuff cores were measured in a simulated near-field environment. This work was directed toward characterizing the interactive tuff-actinide-ground water systems. An effort was initiated to identify the abundance and composition of colloidal materials that occur naturally in ground water since their presence in the repository may affect actinide transport rates. Characterization of the pore structure, fracture frequency, and fracture-lining minerals in tuff cores continued.

\subsubsection{Characteristics and behavior of the waste form}

Studies of the characteristics and behavior of the waste-form materials continued. Investigations were conducted on the dissolution and oxidation behavior of spent fuel and the corrosion and radionuclide-release characteristics of irradiated Zircaloy cladding. Oxidation tests with spent fuel from boiling-water reactors were started (Einziger, 1988a, $1988 \mathrm{~b}$ ), and long-term oxidation tests on spent fuel from pressurized-water reactors continued. Preliminary conceptual models were developed for addressing the oxidation behavior of spent fuel.

Work continued on flow-through experiments using depleted uranium dioxide $\left(\mathrm{UO}_{2}\right)$ pellet fragments to investigate the effects of water chemistry and other test parameters, such as temperature, on the dissolution rate of $\mathrm{UO}_{2}$. An Auger microprobe was used to examine the surface of $\mathrm{UO}_{2}$ particles removed from flow-through columns at various times. As part of the saturated tests with unirradiated $\mathrm{UO}_{2}$, a task plan on the determination of the dissolution rate of the $\mathrm{UO}_{2}$ matrix in J-13 well water by isotope dilution technique has been prepared. This is a continuation of tests designed to investigate the feasibility of determining the dissolution rate of a $\mathrm{UO}_{2}$ matrix in $\mathrm{J}-13$ water. As part of the unsaturated tests with unirradiated $\mathrm{UO}_{2}$, a task plan on surface reactions between $\mathrm{J}-13$ water and $\mathrm{UO}_{2}$ pellets at $90^{\circ} \mathrm{C}$ has been prepared. The principal objective of the test is to reproduce the results from the previous series with regard to uranium release and secondary-phase formation during the water- $\mathrm{UO}_{2}$ reactions.

Corrosion testing and model development for Zircaloy cladding continued. Preliminary conceptual models were developed to address the potential failure of Zircaloy cladding by stress rupture, stress-corrosion cracking, and hydride reorientation. A new pressurized tube apparatus has been constructed for testing hydride precipitation-induced failures that may be coupled with other degradation failure mechanisms.

Experiments to examine the effect of fluoride ions on Zircaloy corrosion were initiated; results from the newly constructed fluoride corrosion apparatus indicate that low $\mathrm{pH}$ and high concentrated fluoride solutions are corrosive to unirradiated Zircaloy.

Experiments to examine the susceptibility of cladding to failure by stress-corrosion cracking continued. The preliminary model for corrosion-cracking failure of Zircaloy cladding is based on a deformation-stress analysis of the Zircaloy cladding and its sur- 
rounding surface layer of zirconium oxide. The model is considered conservative in the sense that, at the first appearance of a through-crack, the cladding is assumed to have failed. The results of this testing program are being used to model the processes involved.

Work continued to define the inventory and distribution of carbon-14 in the fuel cladding. Experiments to study the thermally activated release of gaseous carbon-14 (as carbon dioxide) and tritium from the cladding of irradiated pressurized-water-reactor fuel to the environment also continued. Conceptual models for the release of gaseous carbon-14 at elevated temperatures were developed and checked against the available experimental data. Controlled experimental parameters include temperature, atmosphere, oxide thickness, and cladding history.

To determine the behavior of high-level waste in the form of borosilicate glass, the rate at which borosilicate glass is altered by liquid water and water vapor and the subsequent radionuclide release due to these alteration processes are being investigated. Static tests are under way to (1) test predictions of precipitate-solution equilibria and (2) assess radionuclide release in the advanced stages of reaction.

Long-term unsaturated tests of waste-glass compositions similar to those to be produced at the Defense Waste Processing Facility (high-level waste from Savannah River) and at the West Valley Demonstration Project (commercial high-level waste) continued. Unsaturated tests simulating intermittent contact with liquid water and continual contact with water vapor, and vapor-phase tests in which the glass is exposed to water vapor at a variety of relative humidities and temperatures, are being continued. These tests are being conducted to identify important chemical interactions between the waste form, water, and expected repository materials and to provide a data base against which release rate models can be tested.

Parametric tests to determine important parameters, including materials interactions that may affect the release of radionuclides from waste glasses, were also conducted. Dynamic flow-through leaching experiments to determine the $\mathrm{pH}$ and temperature dependence of kinetic rate constants for the reaction of glass were started, using simplified waste-glass compositions. Work also continued on the development of a chemical model for glass dissolution that has been incorporated in the EQ3/6 geochemical modeling code. Current experimental work is aimed at testing model predictions for the dependence of glass dissolution rates on solution composition.

Work continued on geochemical simulations for waste-form release. The measured steady-state concentrations of uranium, neptunium, and plutonium in solution have been compared to predictions obtained from geochemical simulations of spent-fuel dissolution. Comparisons showed that experimental results could be interpreted in terms of the precipitation of secondary phases and the changing composition and redox potential of the solution.

\subsubsection{Characteristics and behavior of disposal-container materials}

On August 29,1989, the DOE and the NRC conducted a technical exchange on the subject of substantially complete containment. During the exchange, the DOE reviewed its interpretation of the concept of substantially complete containment as presented in the SCP.

Progress was made in investigating potential materials for the disposal container. Six metallic alloys are being evaluated as candidate materials for the container: 304L stainless steel, 316L stainless steel, a high-nickel alloy, oxygen-free copper, a 70/30 copper- 
nickel alloy, and aluminum bronze. An annotated history of the 1981-88 metal-barriers program, which documents the methods used to identify the six candidate materials, was prepared (McCright, 1988).

Criteria for selecting among the six candidate materials for the advanced conceptual design of the waste package were developed. Both the projected performance of the material in the repository environment and the engineering aspects of container production were taken into consideration in developing the selection criteria. The criteria were formally reviewed by an independent peer review panel of six prominent metallurgists and engineers.

A survey was conducted of the degradation modes that could affect the six candidate waste-package container materials in the repository environment. The survey was based on an analysis of the technical literature and included an assessment of the corrosion behavior, oxidation behavior, and metallurgical-phase stability of each of the candidate materials. Parametric studies were initiated to quantify some of the performance criteria for evaluating the candidate container materials, particularly with respect to the localized-corrosion and stress-corrosion behavior of the materials.

Plans for experimental work on the corrosion behavior of copper-base materials have been completed. Work is in progress to assess the corrosion-resistance properties of the copper-based alloys and austenitic materials, including susceptibility to stress corrosion cracking in concentrated $\mathrm{J}-13$ well water. The effect of radiolysis on alloy corrosion will be studied for both alloy groups.

\subsection{PERFORMANCE ASSESSMENT}

Performance assessment is the process of evaluating component, subsystem, or system behavior relative to radiological health and safety or the containment and isolation of radioactive wastes. The objectives of these assessments are (1) to demonstrate compliance with the numerical performance objectives (both preclosure and postclosure) in $10 \mathrm{CFR}$ Part 60 , (2) to support the development of the repository system, and (3) to guide testing during site characterization. The performance-assessment program is discussed in SCP Section 8.3.5.

\subsubsection{Preclosure performance assessment}

The objective of preclosure safety assessment is to predict the probable radiological consequences of repository operations and to compare the consequences with acceptance criteria. Preclosure safety assessment includes the evaluation of risks to repository workers and the general public under both normal operations and accident conditions.

A number of analyses supporting the assessment of preclosure safety were completed. Potential repository structures, systems, and components important to safety were identified (Jardine and Laub, 1988). Assessments of worker and nonworker radiation safety (Laub, 1988) and a preliminary safety analysis for normal operating conditions (Laub et al., 1988) were completed. A preliminary safety analysis for accident conditions and an uncertainty analysis of the radiological consequences of accidents at the repository were conducted. A radiation-safety analysis was also conducted for the exploratory-shaft facility to assist in identifying items important to safety. 
An analysis was initiated to cvaluate the effects of uncertainties in radionuclide source terms and transport mechanisms on the calculation of the radiological consequences of accidents. The uncertainties will be statistically combined to determine accident doses at various confidence levels.

A study is currently being conducted to evaluate criticality safety for intact and consolidated fuel configurations proposed for the repository. Analysis parameters include water immersion, fuel burnup allowances, waste container designs, and geometry control. Accident scenarios will be developed, and the effective neutron-multiplication factor will be calculated. For study cases where the effective neutron-multiplication factor exceeds the required limit of 0.95 , options such as container reconfiguration, neutron absorbers, and filler materials will be evaluated.

\subsubsection{Postclosure performance assessment}

The objective of postclosure performance assessment is to predict the behavior of the repository system and its subsystems after permanent closure in order to evaluate compliance with NRC requirements. Postclosure performance assessments are conducted for the following:

1. Natural barriers (to evaluate the ground-water travel time).

2. Engineered-barrier system (to evaluate containment by the waste packages and the rate of release from the engineered-barrier system after the containment period).

3. Total system (to evaluate waste isolation after permanent closure).

\section{Natural barriers}

Progress in assessing the performance of natural barriers included the evaluation of the ground-water flow system at the site, as presently understood. This included the evaluation of (1) lateral fluid flow at Yucca Mountain (Wang and Narasimhan, 1988); (2) uncertainty in hydrologic parameters (Kaplan and Yarrington, 1989); (3) fluid and heat flow near waste packages (Doughty and Pruess, 1988); (4) gas-phase flow (Tsang and Pruess, 1988); and (5) capillary-driven flow in fractures (Martinez and Prindle, 1988).

Progress in developing calculational models for assessing the performance of natural barriers included the following: (1) evaluating various approaches to calculating groundwater travel time (Kaplan et al., 1989); (2) evaluating the hydrologic effects of constructing the exploratory-shaft facility (Peterson, 1989); (3) analyzing proposed laboratory experiments (Eaton et al., 1989); and (4) developing computational and experimental procedures for predicting flow (Eaton et al., 1988). In addition, a three-dimensional steady-state flow system that takes into account the construction of an exploratory shaft was analyzed.

One- and two-dimensional hydrologic modeling codes have been modified to increase efficiency and capability. Modifications made to LLUVIA, the one-dimensional steady-state code for flow through partiaily saturated porous media, greatly increased the speed of execution. A description of LLUVIA was prepared.

A code was installed to correlate parameters in multivariate stochastic simulations. Tests of the sensitivity of ground-water travel time to assumptions about correlation structure have been initiated. 
Flow calculations with TOUGH, a two-phase flow code, continued. The COVE3A benchmarking problem with 10 grid blocks was run, and the problem with 20 grid blocks was initiated.

Refinement of the semianalytical solution for fluid and heat flow around a waste package in a partially saturated medium continued. Current analysis indicates that, for most cases of practical interest, the region with immobile water may have a near-zero thickness, which indicates there will be a sharp boiling front with a saturation discontinuity. Additional analysis of the region of immobile liquid is being performed.

\section{Engineered-barrier system}

Progress was made in the assessment of engineered-barrier performance. Version 3245.0888 of the EQ3/6 geochemical modeling computer code was released for testing and verification, and final coding for the advanced-conceptual-design version of EQ3/6 was in progress. User's manuals for the modeling and data-base-handling codes were written. Version 3245 is being extensively tested on systems of interest to performance assessment (spent-fuel and glass dissolution, water chemistry in the unsaturated zone, and container-material effects).

A preliminary kinetic model of glass alteration by liquid water, derived from experimentally observed phenomena and basic thermodynamic principles, was developed and incorporated into the EQ3/6 geochemical modeling computer code. The predictions of this model are being checked against new experimental data.

The first version of the waste-package performance-assessment computer code, PANDORA-1, was developed and put into testing. Other progress included the development and testing of the FACSIMILE computer code for simulating nonuniform corrosion of Zircaloy and container materials in the presence of tuff ground water.

\section{Total system}

Progress in the area of total-system performance assessment included the initial documentation of TOSPAC, the total-system performance-assessment code (Dudley et al., 1989). The incorporation of the fracture-transport module (TRANS) into TOSPAC Version 1.1 was completed. The OUTPLOT module, which produces graphs after a water-flow or transport calculation, remains to be included in this version of TOSPAC. Work on the RS/1-TOSPAC interface also continues. Other developments included the adaption of the PORFLO-3 code as a component of the SUMO system computer code. In addition, the results of preliminary analyses of total system performance were compiled to support the design of the exploratory-shaft facility (Peters, 1988; Peterson, 1989).

The elements of a model of volcanic events at the Yucca Mountain site were compiled. Some elements included in the model are (1) a detailed repository plan, including orientation of the repository and the placement, orientation, size, and content of the waste containers; (2) orientations of possible magmatic dikes; (3) existence and orientation of possible magma chambers; and (4) time distribution of past volcanic events in the region surrounding Yucca Mountain.

A preliminary sensitivity analysis of gaseous carbon-14 release was performed; it was based on an analytic solution of the advection-dispersion equation in one dimension. 


\subsubsection{Design analysis}

The third category of performance assessment, design analysis, integrates the performanceassessment program with the design program. In this context, design analysis refers to the performance assessments that are used to develop design requirements and to evaluate the design against those requirements. Work during the period focused on developing the interfaces between the design and performance assessment programs, as well as the process that will be used in establishing the design requirements for the exploratory shaft facility.

\subsubsection{Site-characteristics analysis}

The fourth category of performance assessment, the site-characteristics analysis, integrates the performance-assessment program with the investigations of the site programs. Site characteristics analyses include the following: (1) the development of site conceptual models, scenarios, and process and constitutive models that can be used in performance assessments; (2) model-validation activities, including the testing of any alternative conceptual models or hypotheses; (3) performance-assessment activities to support the site programs, such as test planning, evaluation of potential interferences between and among tests, and the evaluation of the adequacy of the information obtained; and (4) activities to support the performance-confirmation program. The process to evaluate site-characterization results involves comparisons with goals set as a part of performance allocation and comparison with the performance objectives, as described in Section 8.1 of the SCP. During the reporting period, work continued to establish interfaces between the performanceassessment program and the site programs and to develop the program of necessary performance assessments. 


\section{SCHEDULES}

\subsection{SITE CHARACTERIZATION SCHEDULES}

During the reporting periods, the DOE performed an evaluation of the overall program schedule. The program schedule includes milestones for the repository (including scientific investigations of the candidate site), monitored retrievable storage facility, and transportation program elements. The schedule development effort consisted of a detailed examination of specific activity durations with a focus on critical path, near-critical path, and major activities.

In late November 1989, a new proposed program schedule was announced in the Secretary of Energy's report to the Congress titled Report to Congress on Reassessment of the Civilian Radioactive Waste Management Program (DOE, 1989f). The new schedule is based on consideration of the duration required to obtain Yucca Mountain site access; comments from the Nuclear Waste Technical Review Board, the NRC, the State of Nevada, and others; and the work scope described in the SCP and the more-detailed study plans. Factors internal and external to the program, which include delays in the processing of environmental permits, study plan review, and funding levels, may continue to affect the program schedule. Table 3.0 and Figure 3.0 present the new schedule for repositoryprogram major milestones. The schedule was issued for comment, and comments were due by January 15, 1990. The schedule will be finalized after any comments received have been considered.

A cornerstone of the new schedule is a focus on the early evaluation of site suitability of the Yucca Mountain site. With the delay in the start of exploratory shaft construction, DOE plans to take advantage of early surface-based tests, if site access is obtained. This is in concert with a number of suggestions, particularly from the State of Nevada and the Edison Electric Institute, that scientific investigation activities focus on potentially adverse conditions and that efforts be made to evaluate key suitability issues early in the process. This will also allow the DOE to evaluate Nuclear Waste Technical Review Board and NRC suggestions relative to the design of the exploratory shaft facility prior to beginning underground investigations. The DOE continues to believe that both surface-based and underground tests, combined with continuing evaluation of the data as they are obtained, is the cost-effective and timely way to conduct scientific investigations.

Lower-level schedules for the exploratory shaft, surface-based testing, site programs, waste package design, seals design, repository design, and performance assessment are under development and will be presented in future progress reports. 


\section{Table 3.0 - Proposed Major Milestones}

\section{Waste Package}

Start Waste Package Advanced Conceptual Design - 10/92

Start Waste Package License Application Design $\quad$-6/96

Provide Engineered Barrier System Data To Design - 7/98

\section{$\underline{\text { Site }}$}

Start New Surface-Based Testing $\quad-1 / 91$

Complete Deep Unsaturated Zone Drilling - 3/94

\section{Repository}

Start Repository Advanced Conceptual Design - 10/92

Start Repository License Application Design - 6/96

\section{$\underline{\text { Regulatory }}$}

$\begin{array}{ll}\text { Obtain Site Access } & -12 / 90 \\ \text { Issue EIS Notice of Intent } & -10 / 97 \\ \text { Issue EIS Implementation Plan } & -2 / 98 \\ \text { Issue Draft EIS } & -10 / 99 \\ \text { Issue Final EIS } & -3 / 01 \\ \text { Issue Record of Decision } & -4 / 01 \\ \text { Issue Site Recommendation } & \\ \quad \text { Report to the President } & -4 / 01 \\ \begin{array}{l}\text { Submit License Application } \\ \text { to the NRC }\end{array} & -10 / 01\end{array}$

\section{$\underline{\text { ESF }}$}

$\begin{array}{ll}\text { Initiate Final ESF Title II Design } & -3 / 91 \\ \text { Start ESF Site Preparation } & -6 / 92 \\ \text { Start ESF Collar Construction } & -11 / 92 \\ \text { Complete ESF Connection } & -9 / 95 \\ \text { Complete ESF Geologic Drifting } & -11 / 97\end{array}$




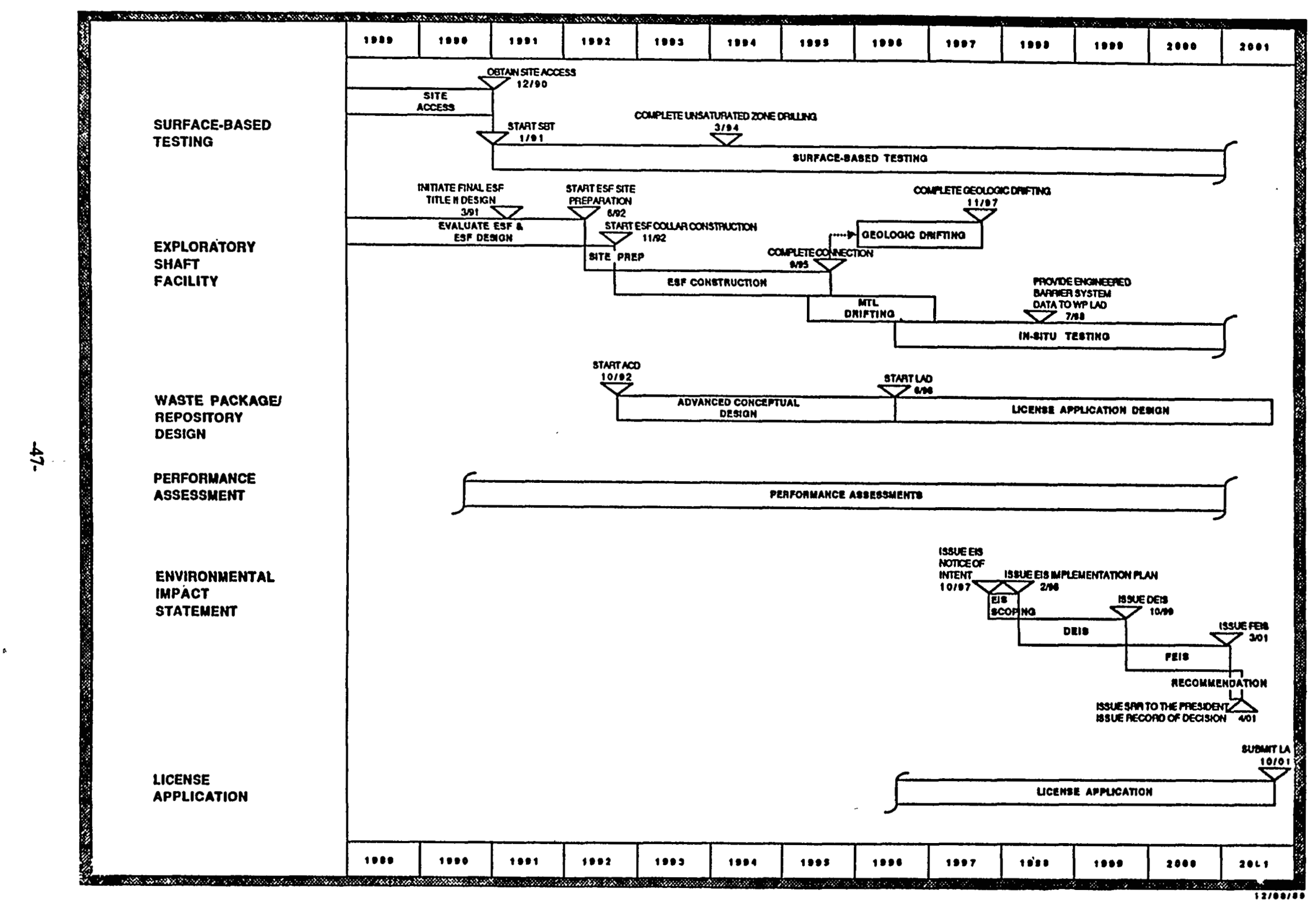

FIGURE 3.0 PROPOSED SITE CHARACTERIZATION SUMMARY SCHEDULE 


\section{REFERENCES}

Bauer, S., L. Costin, and J. F. Holland, 1989. Preliminary Analyses in Support of In Situ Thermomechanical Investigations, SAND88-2785, Sandia National Laboratories, Albuquerque, NM.

Bodvarsson, G. S., A. Nemi, A. Spencer, and M. P. Attanayake, 1988. Preliminary Calculations of the Effects of Air and Liquid-Water Drilling on Moisture Conditions in Unsaturated Rocks, LBL-25073, Lawrence Berkeley Laboratory, Berkeley, CA.

Broxton, D., 1989. Petrography of Phenocryst Chemistry of Volcanic Units at Yucca Mountain: A Comparison of Outcrop and Drill Hole Sample, LA-11503-M3, Los Alamos National Laboratory, Los Alamos, NM.

Carlos, B., 1989. Fracture-Coating Minerals in the Topopah Spring Member and Upper Tuff of Calico Hills From Drill Hole J-13, LA-11504-M5, Los Alamos National Laboratory, Los Alamos, NM.

Chipera, S. J., and D. L. Bish, 1989a. The Occurrence and Distribution of Erionite at Yucca Mountain, Nevada, LA-11663-MS, Los Alamos National Laboratory, Los Alamos, NM.

Chipera, S. J., and D. L. Bish, 1989b. Quantitative X-Ray Diffraction Analyses of Samples Used for Sorption Studies by the Isotope and Nuclear Chemistry Division, LA-11669-MS, Los Alamos National Laboratory, Los Alamos, NM.

Costin, L., and S. Bauer, 1989. Preliminary Analysis of the Excavation Investigation Experiments Proposed for the Exploratory Shaft at Yucca Mountain, Nevada Test Site, SAND87-1575, Sandia National Laboratories, Albuquerque, NM.

Crowe, B., C. Harrington, L. McFadden, F. Wells, B. Turrin, and D. Champion, 1988. Preliminary Geologic Map of the Lathrop Wells Volcanic Center, LA-UR-884155, Los Alamos National Laboratory, Los Alamos, NM.

Czarnecki, J. B., 1989. "Preliminary Simulations Related to a Large Horizontal Hydraulic Gradient at the North End of Yucca Mountain, Nevada," American Geophysical Union, EOS, vol. 70, No. 15, p. 321.

Deere, D. U., 1989. Letter from D.U. Deere (Chairmen, Nuclear Waste Technical Review Board) to T. Isaacs (DOE), August 11, 1989, concerning configuration and construction of exploratory shafts.

DOE (U.S. Department of Energy), 1986. Final Environmental Assessment: Yucca Mountain Site, Nevada Research and Development Area Nevada, Nevada, DOE/ RW-0073, Washington D.C.

DOE (U.S. Department of Energy), 1988a. Environmental Monitoring and Mitigation Plan for Site Characterization: Yucca Mountain Site, Nevada Research and Development Area, Nevada, DOE/RW-0208 (Rev. 2), Washington, D.C. 
DOE (U.S. Department of Energy), 1988b. Section 175 Report: Secretary of Energy Report to the Congress Pursuant to Section 175 of the Nuclear Waste Policy Act as Amended, DOE/RW-0205, Washington, D.C.

DOE (U.S. Department of Energy), 1988c. Site Characterization Plan: Yucca Mountain Site, Nevada Research and Development Area, Nevada, 8 Volumes, DOE/RW-0199, Washington, D.C.

DOE (U.S. Department of Energy), 1988d. Yucca Mountain Project Exploratory Shaft Facility Title I Design Summary Report, 4 Volumes, YMP/88-20, Las Vegas, NV.

DOE (U.S. Department of Energy), 1988e. Surface-Based Investigations Plan, 4 Volumes, YMP/88-25, Nevada Operations Office, Las Vegas, NV.

DOE (U.S. Department of Energy), 1988f. Yucca Mountain Project Site Atlas, YMP/ 88-21, Nevada Operations Office, Las Vegas, NV.

DOE (U.S. Department of Energy), 1989a. Review Record Memorandum, Exploratory Shaft Facility (ESF) Title I Design Acceptability Analysis and Comparative Evaluation of Alternative ESF Locations, YMP/89-3, Las Vegas, NV.

DOE (U.S. Department of Energy), 1989b. Technical Assessment Review Notice: Geologic and Geophysical Evidence Pertaining to Structural Geology in the Vicinity of the Proposed Exploratory Shaft, Yucca Mountain Project Office, Las Vegas, Nevada.

DOE (U.S. Department of Energy), 1989c. Integrated Data System Title I Preliminary Design Technical Assessment Review Record Memorandum, L89-ESF-JHM-014, Las Vegas, NV.

DOE (U.S. Department of Energy), 1989d. Exploratory Shaft Facility (ESF) Subsystem Design Requirements Document (SDRD) for Title II, YMP/CC-0003 (Rev. 0), Las Vegas, NV.

DOE (U.S. Department of Energy), 1989e. The Yucca Mountain Project Reference Information Base, YMP/CC-0002, Las Vegas, NV.

DOE (U.S. Department of Energy), 1989f. Report to Congress on Reassessment of the Civilian Radioactive Waste Management Program, DOE/RW-0247, Washington, D.C.

Doughty, C., and K. Pruess, 1988. A Similarity Solution for Two-Phase Fluid and Heat Flow Near High-Level Nuclear Waste Packages Placed in Porous Media, SAND88-7071A, Sandia National Laboratories, Albuquerque, NM.

Dudley, A, R. Peters, M. Tierney, and E. Klavetter, 1989. Total System Performance Assessment Code (TOSPAC): Volume 1: Physical and Mathematical Basis, SAND85-0002, Sandia National Laboratories, Albuquerque, NM.

Eaton, R., N. Bixler, and R. Peters, 1988. Computational and Experimental Procedures for Predicting Flow Through Low-Permeability, Partially Saturated, Fractured Rock, SAND88-2626A, Sandia National Laboratories, Albuquerque, NM. 
Eaton, R., R. Dykhuizen, and A. Russo, 1989. Analysis of Proposed Laboratory Experiments in Partially Saturated, Small-Pore Fractured Rock, SAND89-0074A, Sandia National Laboratories, Albuquerque, NM.

Easterling, R. C., and I. J. Hall, 1988. Additional Underground Test Data Required for Yucca Mountain Repository Characterization, SAND87-2073, Sandia National Laboratories, Albuquerque, NM.

Einziger, R. E., 1988a. Test Plan for Thermogravimetric Analyses of BWR Spent Fuel Oxidation, PNL-6745/UC/70, Pacific Northwest Laboratory, Richland, WA.

Einziger, R. E., 1988b. Test Plan for Long-Term, Low-Temperature Oxidation of BWR Spent Fuel, PNL-6427/UC/70, Pacific Northwest Laboratory, Richland WA.

Furgerson, R. B., 1989. Remote-Reference Magnetic Survey of the Nevada Test Site and Vicinity, U.S. Geological Survey Open-File Report 82-465, p. 142.

Golder, 1989. Evaluation of Alternative ESF Shaft Construction Methods and Test Sequences for Yucca Mountain Project Office, 833-1017.116, Golder Associates Inc., Redmond, WA.

Hardy, N. P., and C. N. St. John, 1988. Underground Repository Design Methodology for a Repository in Tuff, SAND88-7059A, Sandia National Laboratories, Albuquerque, NM.

Jardine, L. J., and T. Laub, 1988. Use of Performance Assessments to Generate a Repository Q-List, SAND88-0140A, Sandia National Laboratories, Albuquerque, NM.

Kaplan, P., E. Klavetter, and R. Peters, 1989. Approaches to Groundwater Travel Time, SAND88-2868C, Sandia National Laboratories, Albuquerque, NM.

Kaplan, P., and L. Yarrington, 1989. Modeling the Uncertainties in the Parameter Values of a Layered, Variably Saturated Column of Volcanic Tuff Using the Beta Probability Distribution, SAND88-2247C, Sandia National Laboratories, Albuquerque, NM.

Kiciman, O. K, and N. A Abrahamson, 1988. A Probabilistic Estimation of Seismic Damage at Waste-Handling Facilities of a Repository Located at Yucca Mountain. Nevada, SAND88-7067A, Sandia National Laboratories, Albuquerque, NM.

Kirchoff-Stein, K. S., D. A. Ponce, and B. A. Chochel, 1989. Preliminary Aeromagnetic Map of NTS and Vicinity, Nevada, U.S. Geological Survey Open-File Report 89-446.

Laub, T., 1988. Assessment of Worker and Non-Worker Radiological Safety of a Repository, SAND88-0292A, Sandia National Laboratories, Albuquerque, NM.

Laub, T., L. J. Jardine, C. Ma, R. Sit, S. Zavosky, and D. Hartsann, 1988. Preliminary Radiological Safety Analysis for Normal Operations of a Prospective Yucca Mountain Repository, SAND87-2070C, Sandia National Laboratories, Albuquerque, NM. 
Loux, R. R., 1989a. Letter from R. R. Loux (State of Nevada) to C. Gertz (DOE), May 30,1989 , transmitting State of Nevada's comments on the ESF design acceptability analysis.

Loux, R. R., 1989b. Letter from R. R. Loux (State of Nevada) to S. Rousso (DOE), September 1, 1989, transmitting State of Nevada's comments on the DOE Site Characterization Plan.

Ma, C. W., and L. J. Jardine, 1988. Offsite Radiation Doses Resulting from Seismic Events at the Yucca Mountain Repository, SAND88-7066A, Sandia National Laboratories, Albuquerque, NM.

Martinez, M., and R. Prindle, 1988. Capillary-Driven Flow in a Fracture Located in a Porous Medium, SAND84-1697, Sandia National Laboratories, Albuquerque, NM.

McCright, R. D., 1988. An Annotated History of Container Candidate Material Selection, UCID-21472, Lawrence Livermore National Laboratory, CA.

McKeegan, K. D., D. Phinney, V. M. Oversby, M. Buchholtz-tenBrink, and D. K. Smith, 1988. Uranium Transport in Topopah Spring Tuff: An Ion-Microscope Study, UCRL-99734, Lawrence Livermore National Laboratory, Livermore, CA.

Moore, L. M., F. M. Byers, and D. E. Broxton, 1989. Statistical Test of Reproducibility and Operator Variance in Thin-Section Modal Analysis of Textures and Phenocrysts in the Topopah Spring Member, Drill Hole USW VH-2, Crater Flat, Nye County, Nevada, LA-11452-MS, Los Alamos National Laboratory, Los Alamos, NM.

Nimick, F., and R. Peters, 1989. Relevance of Partial Saturation to the Mechanical Behavior of Tuffs, SAND88-2521C, Sandia National Laboratories, Albuquerque, NM.

Nitsche, H., E. M. Standifer, S. C. Lee, R. C. Gatti, and D. B. Tucker, 1989. Solubility and Speciation Studies of Waste Radionuclides Pertinent to Geologic Disposal at Yucca Mountain: Results on Neptunium, Plutonium and Americium in J-13 Groundwater October 1, 1985 - September 30, 1987, LBL-27157, Lawrence Berkeley Laboratory, Berkeley, CA.

NRC (U.S. Nuclear Regulatory Commission), 1988a. Qualification of Existing Data for High-Level Waste Geologic Repositories, NUREG-1298, prepared by W.D. Altman, J.P. Donnelly, and J.E. Kennedy, Washington, D.C.

NRC (U.S. Nuclear Regulatory Commission), 1988b. Technical Position on Items and Activities in the High-Level Waste Geologic Repository Program Subject to Quality Assurance Requirements, NUREG-1318, prepared by A.B. Duncon, S.G. Bilhorn, and J.E. Kennedy, Washington, D.C.

NRC (U.S. Nuclear Regulatory Commission), 1989. NRC Staff Site Characterization Analysis of the Department of Energy's Site Characterization Plan, Yucca Mountain Site, Nevada, NUREG-1347, prepared by the Office of Nuclear Material Safety and Safeguards, Washington D.C.

O'Brien, P., 1989. OGR Repository-Specific Rod Consolidation Study: Effect on Costs, Schedules, and Operations at the Yucca Mountain Repository, SAND86-2357, Sandia National Laboratories, Albuquerque, NM. 
Peters, R. R., 1988. Hydrologic Technical Correspondence in Support of the Site Characterization Plan, SAND88-2784, Sandia National Laboratories, Albuquerque, NM.

Peterson, A., 1989. Technical Correspondence in Support of an Evaluation of the Hydrologic Effects of Exploratory Shaft Facility Construction, SAND88-2936, Sandia National Laboratories, Albuquerque, NM.

Reheis, M. C., and J. S. Noller, 1989. New Perspective on Quaternary Faulting in the Southern Walker Lane, Nevada, Nevada Bureau of Mines and Geology Open-File Report 89-1, pp. 57-61.

Reheis, M. C., 1989. "Applications of the Morphology and Genesis of Desert Soils to Quaternary Studies in the Southwestern United States," from the International Geological Congress, Washington, D.C., v. 2, pp. 684.

Richardson, A., and C. M. St. John, 1988. A Concrete Shaft Liner Design Methodology for Nuclear Waste Repositories, SAND88-7052, Sandia National Laboratories, Albuquerque, NM.

Richardson, A. M., B. Schmidt, and M. Christopher, 1988. A Proposed Concrete Shaft Liner Design Method for Underground Nuclear Waste Repositories, SAND 88-7120A, Sandia National Laboratories, Albuquerque, NM.

Robison, J. H., D. M. Stephens, R. R. Luckey, and D. A. Baldwin, 1988. Water Levels in Periodically Measured Wells in the Yucca Mountain Area, Nevada, 1981-87, U.S. Geological Survey Open File Report 88-468.

Saltus, R. W., and D. A. Ponce, 1988. Aeromagnetic Map of Nevada-Las Vegas Sheet, Nevada Bureau of Mines and Geology Map 95, scale 1:250,000.

Sanders, M., 1988. Description of Ground Motion Data Processing Codes, SAND 87-1176, Sandia National Laboratories, Albuquerque, NM.

Sass, J. H., A. H. Lachenbrunch, W. W. Dudley Jr., S. S. Priest, and R. J. Munroe, 1988. Temperature, Thermal Conductivity, and Heat Flow near Yucca Mountain Nevada: Some Tectonic and Hydrologic Implications, USGS Open File Report 87-649, 188p.

Scheetz, B. E., and D. M. Roy, 1989. Reactivity of a Tuff-Bearing Concrete: CL-40 CON-14, LA-11532-MS, Los Alamos National Laboratory, Los Alamos, NM.

Scott, R. B., 1989. Isostatic Uplift, Crustal Attenuation, and the Evolution of an Extensional Detachment System in Southwestern Nevada, Nevada Bureau of Mines and Geology Open-File Report 89-1, pp. 19-26.

SNL (Sandia National Laboratories), 1987. Site Characterization Plan Conceptual Design Report, SAND84-2641, 6 Vol., Sandia National Laboratories, Albuquerque, NM.

Stinton, P. O., 1989. "Characterization of the Large Hydraulic Gradient Beneath the North End of Yucca Mountain, Nevada" [abs.], AGU, EOS, vol. 70, No. 15, p. 321.

Subramanian, C. V., and L. J. Jardine, 1988. Evaluation of Site-Generated Radioactive Waste Treatment and Disposal Methods for the Yucca Mountain Repository, SAND88-1937, Sandia National Laboratories, Albuquerque, NM. 
Subramanian, C. V., C. L. Wu, C. D. Degrabrielle, and S. D. Leftwich, 1988. Seismic Design Study of the Waste-Handling Building at the Prospective Yucca Mountain Nuclear Waste Repository, SAND87-1915C, Sandia National Laboratories, Albuquerque, NM.

Subramanian, C. V., A. H. Hadjian, J. King, and R. P. Kennedy, 1989. Preliminary Sei'smic Design Cost-Benefit Assessment of the Tuff Repository Waste Handling Facilities, SAND88-1600, Sandia National Laboratories, Albuquerque, NM.

Swadley, W. C., and D. L. Hoover, 1989. Geologic Map of the Surficial Deposits of the Topopah Spring Quadrangle, Nye County, Nevada, U.S. Geological Survey Miscellaneous Investigations Series Map I-2018, scale 1:48,000.

Thenhaus, P. C., and T. P. Barnhard, 1989. "Regional Termination and Segmentation of Quaternary Fault Belts in the Great Basin Nevada and Utah," Bulletin of the Seismological Society of America, v. 79, no. 5.

Triay, I. R., and R. S. Rundberg, 1989a. "Application of Deconvolution to the Analysis of Univalent Ion-Exchange Isotherms in Zeolites $\mathrm{X}$ and $\mathrm{Y}$, " Zeolites, vol. 9., pp. 217-223.

Triay, I. R., and R. S. Rundberg 1989b. "Deconvolution of Multivalent Cation Exchange Isotherms," The Journal of Physical Chemistry, vol. 93, No. 14, pp. 5617-5623.

Tsang, Y., and K. Preuss, 1988. Gas Phase Flow Effects on Moisture Migration in the Unsaturated Zone at Yucca Mountain, SAND88-7073A, Sandia National Laboratories, Albuquerque, NM.

Wallace, K, and D. Zerga, 1988. An Analysis of Air Cooling Prior to Reentering a Drift Containing Emplaced Commercial Nuclear Waste, SAND87-7076C, Sandia National Laboratories, Albuquerque, NM.

Wang, J. S. Y., and N. T. Narasimhan, 1988. Hydrologic Modeling of Vertical and Lateral Movement of Partially Saturated Fluid Flow Near a Fault Zone at Yucca Mountain, SAND87-7070, Sandia National Laboratories, Albuquerque, NM.

Weston, 1989. Evaluation of Additional Drifting for Site Characterization of Yucca Mountain, Roy F. Weston, Inc., Washington, D.C.

Yang, I. C., A. K. Turner, T. M. Sayre, and P. Montazer, 1988. Triaxial-Compression Extraction of Pore Water from Unsaturated Tuff, Yucca Mountain, Nevada, U.S. Geological Survey Water-Resources Investigation Report 88-4189. 


\section{ACRONYM LIST}

$\begin{array}{ll}\text { AECL } & \text { - Atomic Energy Canada, Limited } \\ \text { BLM } & \text { - Bureau of Land Management } \\ \text { CFR } & \text { - Code of Federal Regulations } \\ \text { DOE } & \text { - Department of Energy } \\ \text { EIS } & \text { - Environmental Impact Statement } \\ \text { ESF } & \text { - Exploratory shaft facility } \\ \text { IDAS } & \text { - Integrated data acquisition system } \\ \text { NDEP } & \text { - Nevada Division of Environmental Protection } \\ \text { NRC } & \text { - Nuclear Regulatory Commission } \\ \text { OCRWM } & \text { - Office of Civilian Radioactive Waste Management } \\ \text { QA } & \text { - Quality assurance } \\ \text { QAP } & \text { - Quality assurance plan } \\ \text { QAPD } & \text { - Quality assurance program description } \\ \text { QAR } & \text { - Quality assurance requirements } \\ \text { ROWR } & \text { - Right-of-way reservation } \\ \text { SCP } & \text { - Site characterization plan } \\ \text { USFWS } & \text { - United States Fish and Wildlife Service }\end{array}$

$-55-$ 


\section{BIBLIOGRAPHY}

The following is a bibliography of selected documents that provide additional information to that which is provided in the text of the report. The bibliography was developed based on a systematic search of the Energy Data Base (EDB). The EDB is the principal data base of an information management system maintained by the DOE Office of Scientific and Technical Information at Oak Ridge, TN. The EDB contains unclassified energy-related scientific and technical information. The bibliography contains those pertinent documents available in the EDB as of September 30, 1989.

Copies of DOE and DOE sponsored documents identified in the bibliography can be ordered from:

National Technical Information Service

U.S. Department of Commerce

5285 Port Royal Road

Springfield, VA 22161 
Arthur, R. C., and W. M. Murphy, 1988. "Gas-Water-Rock Interactions During Isothermal Boiling In Partially Saturated Tuff at $100^{\circ} \mathrm{C}$ and $0.1 \mathrm{MPa}$," from the International Symposium on the Thermodynamics of Natural Processes, Strasbourg, FR, July 25, 1988, PNL-SA-15538, Pacific Northwest Laboratory, Richland, WA.

Mass-transfer calculations using the Rayleigh distillation equation and the EQ3/6 software package show that pore water at Yucca Mountain will be strongly affected by open-system boiling at $100^{\circ} \mathrm{C}$ and $0.1 \mathrm{MPa}$. Variations in $\mathrm{pH}$ range from +1 to +4 units, and are caused by volatile weak electrolyte interactions as $\mathrm{CO}_{2}$ exsolves from the aqueous phase. Protolysis of $\mathrm{H}_{4} \mathrm{SiO}_{4}$ and mineral-solution reactions can moderate the increase in $\mathrm{pH}$ initially, but are not effective when boiling vaporizes more than approximately $0.2 \mathrm{wt} \%$ of the water.

Bates, J. K., T. J. Gerding, and E. Veleckis, 1989. "Repository-Relevant Testing Applied to the Yucca Mountain Project," from the National Meeting of the American Chemical Society, Dallas, TX, April 9, 1989, Argonne National Laboratory, IL.

A repository environment poses a challenge to developing a testing program because of the diverse nature of conditions that may exist at any given time during the life of the repository. A starting point is to identify whether any potential water contact modes are particularly deleterious to the waste form performance, and whether any interactions between materials present in the waste package environment need to be accounted for during modeling the waste form reaction. This paper describes testing that has been performed on simulated glass and unirradiated $\mathrm{UO}_{2}$.

Bates, J. K., T. J. Gerding, W. L. Ebert, J. J. Mazer, and B. M. Biwer, 1988. NNWSI [Nevada Nuclear Waste Storage Investigation] Waste Form Testing at Argonne National Laboratory, Semiannual Report, July-December 1987, Argonne National Laboratory, IL.

Examination of simulated defense glass (SRL 165 black frit based) and simulated West Valley glass (ATM-10) with water under conditions that may exist at Yucca Mountain, Nevada were conducted. The tests on SRL 165 glass indicate the nonstoichiometric release of lithium, sodium, boron, and actinide elements. The tests on ATM-10 glass have not progressed enough to assess the glass reaction. The influence of penetrating gamma radiation on the reaction of synthetic nuclear waste glasses in tuff ground water was also investigated. Modified static leaching experiments were performed under radiation exposures with ground water acidified by nitrous and nitric acids radiolytically produced in the air. The glass reaction, as measured by the release of glass species and the thickness of an alteration layer formed on the glass surface, was not measurably affected by radiation.

Battelle Memorial Institute, 1988. Interface Management for the Yucca Mountain Project, $\mathrm{DOE} / \mathrm{CH} / 10290-\mathrm{Tl}$, Columbus, $\mathrm{OH}$.

This report addresses the physical interfaces that need to be controlled on the Yucca Mountain Project. Physical interfaces are interactions between physical elements of the mined geologic disposal system; for example, the repository shafts will interface with the exploratory shaft facility. 
Bauer, L. R., 1988. Gas Phase Migration of C-14 Through Barrier Materials Applicable for Use in a High-Level Nuclear Waste Repository Located in Tuff, DOE/OR/ 00033-T419, Purdue University, Lafayette, IN.

A study of the movement of carbon-14 through materials applicable for use in a high-level radioactive waste repository located in tuff has been conducted. Diffusion coefficients for crushed tuff, bentonite, and a $90: 10 \%$ by weight mixture of crushed tuff and bentonite were measured for two diffusion lengths. The ability of carbon-14 to penetrate a microsilica-containing portland cement mortar was also examined. The specimens were subjected to uniaxially applied compressive loads prior to the diffusion tests to simulate the onset of environmentally induced microcracks.

Bauer, S. J., L. S. Costin, E. P. Chen, and J. R. Tillerson, 1989. "Excavation Response in Geological Repositories for Radioactive Waste," from NEA Workshop on Excavation Effects on the Engineering Design and Safety Performance of an Underground Repository for Radioactive Waste, Winnipeg, Canada, April 26-28, 1988.

Models are currently being developed to support thermal, mechanical, and thermomechanical aspects of design and performance assessment of a proposed repository at Yucca Mountain. Credibility of these models, and therefore of design and performance analyses, will in part be determined through comparison of calculated and measured response for large-scale field experiments. This paper discusses the models being developed, the rationale behind the model development, and analyses of experiments performed at G-Tunnel on the Nevada Test Site and those planned as part of site characterization at Yucca Mountain.

Bingham, F. W., 1988. "A 'Top-Level' Strategy to Guide the Characterization of Yucca Mountain," from the American Nuclear Society Annual Meeting, San Diego, CA, June 12, 1988, SAND-88-0077C, Sandia National Laboratory, Albuquerque, NM.

The basis for plans to characterize the Yucca Mountain site is a detailed strategy for collecting the data that the DOE expects to use in assessing compliance with regulations.' At its highest, least detailed level, the strategy rests simply on a few fundamental expectations about the behavior of a repository system at Yucca Mountain. This paper explains how the "top level" strategy was formulated and points out the features of the site on which fundamental expectations are based.

Bish, D. L, 1989. Evaluation of Past and Future Alterations in Tuff at Yucca Mountain, Nevada, Based on the Clay Mineralogy of Drill Cores USW G-1, G-2, and G-3, LA-10667-MS, Los Alamos National Laboratory, Los Alamos, NM.

For predictive purposes, it is important to understand the alteration history of Yucca Mountain, in particular how the tuff responds to changing conditions such as elevated temperatures. The clay mineralogy of tuff has been examined using $\mathrm{X}$-ray powder diffraction, and approximation temperatures of alteration have been determined using available clay mineral data and fluid inclusion analyses. The clay minerals are predominately interstratified illite/ smectites, with minor amounts of chloride, kaolinite, and interstratified chlorite/ smectite. 
Bish, D. L., and S. J. Chipera, 1989. Revised Mineralogic Summary of Yucca Mountain, Nevada, LA-11497-MS, Los Alamos National Laboratory, Los Alamos, NM.

The three-dimensional mineral distribution at Yucca Mountain, was evaluated using quantitative X-ray powder diffraction analysis. All data were obtained from core cuttings or sidewall samples obtained from drill holes at and around Yucca Mountain. The data support the presence of several zones of mordenite and clinoptilolite-heulandite. New data on several deep clinoptilolite-heulandite samples coexisting with analcime show that they are heulandite.

Blejwas, T. E., R. M. Zimmerman, and L. E. Shephard, 1989. Proceedings of the Nuclear Energy Agency (NEA) Workshop on Excavation Effects on the Engineering Design and Safety Performance of an Underground Repository for Radioactive Waste pp. 175-186.

Plans for site characterization testing and constructing an exploratory shaft facility (ESF) at Yucca Mountain have been influenced by the construction and monitoring of stable openings in G-Tunnel on the Nevada Test Site. The G-Tunnel provides access for testing in a thin bed of unsaturated welded tuff that is similar to that at Yucca Mountain. The data from the experiments in the ESF will be used to validate analytical methods for predicting the response of underground openings to the excavation process and to the heat generated by the waste.

Blejwas, T. E., 1989. "Experiments in Rock Mechanics for the Site Characterization of Yucca Mountain," from the US Symposium on Rock Mechanics, Morgantown, WV, June 19-22, 1989, SAND-88-2650C, Sandia National Laboratories, Albuquerque, NM.

To support licensing of a repository, numerous carefully controlled and documented rock mechanics experiments are required. Data from the experiments will be used to validate advanced analytical methods, expand the database for empirical approaches, demonstrate rock-mass behavior under simulated repository conditions, and provide input for repository performance assessments. Although some experiments are relatively straightforward, others will require development or modification of state-of-the-art techniques, equipment, and instruments.

Bolivar, S. L., D. E. Broxton, D. L. Bish, F. M. Byers, B. H. Carlos, S. S. Levy, D. T. Vaniman, and S. J. Chipera, 1989. "Mineralogy-Petrology Studies and Natural Barriers at Yucca Mountain, Nevada," from the Nuclear Waste Isolation in the Unsaturated Zone: FOCUS '89, September 18-21, 1989, LA-UR-89-2952, Los Alamos National Laboratory, NM.

The Yucca Mountain site is underlain by a thick sequence of lithologically variable pyroclastic rocks. The candidate host rock is a densely welded devitrified tuff, the Topopah Spring Member of the Paintbrush Tuff. The types, distributions, and abundances of both rock-matrix and fracture-lining minerals along potential transport pathways between the proposed repository and the accessible environment are described. The work emphasized the distribution of secondary minerals such as zeolites, clays, and iron and manganese oxides because of their ability to 
selectivity sorb or retard certain radionuclides. The conditions under which mineral assemblages form and their thermal stabilities were also evaluated.

Bonano, E. J., P. A. Davis, R. L. Bras, and P. K. Kitanidis, 1988. "Methodology for Estimating Groundwater Travel Times at a Nuclear Waste Repository using a Physically Based Geostatistical Approach," from the International Geostatistics Congress; Avignon, France, Sept 1988, SAND-87-2226C, Sandia National Laboratories., Albuquerque, NM.

This paper summarizes the results of an investigation to test a methodology for estimating ground-water travel times at potential high-level nuclear waste repository sites. The procedure is based on parameter estimation that uses available hydraulic head and transmissivity observations and includes uncertainty in the boundary head values in the estimation of a transmissivity field.

Buscheck, T. A, and J. J. Nitao, 1988. Preliminary Scoping Calculations of Hydrothermal Flow in Variably Saturated, Fractured, Welded Tuff During the Engineered Barrier Design Test at the Yucca Mountain Exploratory Shaft Test Site, UCID- 21671, Lawrence Livermore National Laboratory, Livermore, CA.

The hydrothermal system of Yucca Mountain was modeled as a discrete fracture/matrix system, using the integral finite difference code TOUGH and the best available data on the fracture and matrix properties of the Topopah Spring densely welded tuff. Calculations related to the volume of undisturbed rock in connection with various temperatures in different conditions are presented.

Buscheck, T. A, and J. J. Nitao, 1988. Estimates of the Width of the Wetting Zone Along a Fracture Subjected to an Episodic Infiltration Event in Variably Saturated, Densely Welded Tuff, UCID-21579, Lawrence Livermore National Laboratory, CA.

A central issue to be addressed at Yucca Mountain is the role which fractures will play as the variably saturated, fractured rock mass surrounding the waste package responds to heating, cooling, and episodic infiltration events. Understanding the role of fractures during such events will, in part, depend on the ability to make geophysical measurements of perturbations in the moisture distribution in the vicinity of fractures. In this study, the details of the perturbation in the moisture distribution in and around a fracture subjected to an episodic infiltration event are examined. To model this system, the TOUGH hydrothermal code and fracture and matrix properties considered relevant to the welded ash flow tuff found in the Topopah Spring member at Yucca Mountain as well as in the Grouse Canyon member within G-Tunnel at the Nevada Test Site were used. The calculations provide insight into the anticipated spatial and temporal resolution obtainable through the use of the geophysical techniques being considered.

Carr, M. D., and J. C. Yount, 1988. Geologic and Hydrologic Investigations of a Potential Nuclear Waste Disposal Site at Yucca Mountain, Southern Nevada, USGSBULL-1790, Geological Survey, Denver, CO.

The deep water table, closed-basin ground-water flow, potentially favorable host rock, and sparse population have made Yucca Mountain area a viable candidate 
for a radioactive waste disposal site. Yucca Mountain, however, lies within the southern Great Basin, a region of known contemporary tectonics and young volcanic activity. The U.S. Geological Survey has been conducting extensive studies to evaluate the geologic setting of Yucca Mountain, as well as the timing and rates of tectonic and volcanic activity in the region. A workshop was convened by the Geologic Survey in Denver, Colorado, on August 19-21, 1985, to review the scientific progress and direction of these studies. This collection of papers represents the results of some of the studies presented at the workshop.

Day, R. A., 1988. Preliminary Technique Assessment for Nondestructive Evaluation Certification of the NNWSI [Nevada Nuclear Waste Storage Investigations] Disposal Container Closure, UCID-21323, Lawrence Livermore National Laboratory, Livermore, CA.

An evaluation of methods to certify closure of waste containers was performed. It is concluded that the waste container closure weld can best be nondestructively examined by a combination of ultrasonics and liquid penetrants. Ultrasonic and liquid penetrant methods can examine all closure methods currently being considered, including fusion welding and inertial welding.

Department of Energy, Office of Civilian Radioactive Waste Management, 1988. Site Characterization Plan Overview: Yucca Mountain Site, Nevada Research and Development Area, Nevada, DOE/RW-0198, Washington, D.C.

The Site Characterization Plan (SCP) overview was prepared to help the public understand both the SCP and the site characterization program in general. The overview presents summaries of selected topics covered in the SCP. The organization of the overview is similar to that of the SCP, with brief descriptions of the Yucca Mountain site, the repository, and the containers in which the waste would be packaged, followed by a discussion of the characterization program to be carried out at the Yucca Mountain site.

Department of Energy, Office of Civilian Radioactive Waste Management, 1989. 1988 Bulletin Compilation and Index, DOE/RW-02221, Washington, D.C.

This document is published to provide current information about the national program for managing spent fuel and high-level radioactive waste. This document is a compilation of bulletin issues from the 1988 calendar year.

Department of Energy, Office of Civilian Radioactive Waste Management, 1988. Quarterly Report on Program Cost and Schedule, Fourth Quarter FY 1988, DOE/ RW-0188-3, Washington, D.C.

This report is intended to provide a summary of the cost and schedule performance for the Civilian Radioactive Waste Management Program. Performance data are presented for each of the major program elements. Also included in this report is the status of the Nuclear Waste Fund revenues and disbursements. This report includes performance data through September 1988. 
Department of Energy, Office of Civilian Radioactive Waste Management, 1989. Quarterly Report on Program Cost and Schedule, First Quarter FY 1989, DOE/ RW-0225, Washington, DC.

This report is intended to provide a summary of the cost and schedule performance for the Civilian Radioactive Waste Management Program. Performance data are presented for each of the major program elements. Also included in this report is the status of the Nuclear Waste Fund revenues and disbursements. This report includes performance data through December 1988.

Department of Energy, Office of Civilian Radioactive Waste Management, 1989. Quarterly Report on Program Cost and Schedule, Second Quarter FY 89, DOE/ RW-0225-1, Washington, DC.

This report is intended to provide a summary of the cost and schedule performance for the Civilian Radioactive Waste Management Program. Performance data are presented for each of the major program elements. Also included in this report is the status of the Nuclear Waste Fund revenues and disbursements. This report includes performance data reported through March 1989.

Department of Energy, Office of Civilian Radioactive Waste Management, 1989. Draft Reclamation Program Plan for Site Characterization Yucca Mountain Project, DOE/RW-0244, Washington, DC.

As part of its obligations under the Nuclear Waste Policy Act, as amended, the DOE has developed an environmental program that is to be implemented during site characterization at Yucca Mountain. A program for the reclamation of areas disturbed by site characterization is part of the overall environmental program for that site. This Reclamation Program Plan (RPP) describes the reclamation policy of the DOE for the Yucca Mountain site and presents an overview of the reclamation program. The objective of the RPP is to return land disturbed by sitecharacterization activities to a stable ecological state with a form and productivity similar to the predisturbed state.

Ebert, W. L., J. K. Bates, T. A. Abrajano, and T. J. Gerding, 1989. "The Influence of Penetrating Gamma Radiation on the Reaction of Simulated Nuclear Waste Glass in Tuff Ground Water," from the Annual Meeting of the American Ceramic Society, Indianapolis, IN, April 23-27, 1989, Argonne National Laboratory, IL.

Static leaching experiments have been performed to determine the influence of penetrating gamma radiation on the reaction of simulated nuclear waste glass in tuff ground water at $90^{\circ} \mathrm{C}$. Both the leachates and the reacted glass monoliths were analyzed to characterize the reaction. Radiation was seen to acidify the leachates, but the high bicarbonate content of the ground water prevented the pHs from dropping below 6.4. The glass reaction tended to raise the $\mathrm{pH}$. Glass based on SRL 165 black frit and PNL 76-68 glass compositions were leached. The SRL 165 type glasses were quite durable and unaffected by radiation. The PNL 76-68 glasses were much less durable, with the durability decreasing as the exposure rate was increased. 
Ehgartner, B. L. and R. C. Kalinski, 1988. A Synopsis of Analyses (1981-87) Performed to Assess the Stability of Underground Excavations at Yucca Mountain, SAND-88-2294, Sandia National Laboratories, Albuquerque, NM.

This paper reviews 14 analyses that were performed during the course of 7 years to assess the preclosure stability of underground excavations for a potential nuclear waste repository located at Yucca Mountain. The analyses were primarily based on thermomechanical models of the conceptual design of shafts and drifts. The material properties, codes, and design configurations used in the analyses varied because of the acquisition of additional data and refinement in codes and design over that period of time. However, all the analyses indicate that shafts and drifts can be constructed and will remain stable with minimum ground support through decommissioning of the repository.

Farmer, J. C., and R. D. McCright, 1988. Localized Corrosion and Stress Corrosion Cracking of Candidate Materials for High-Level Radioactive Waste Disposal Containers in the US: A Literature Review, from the Materials Research Society; Berlin, DE, October 1988, UCRL-98756, Lawrence Livermore National Laboratory, Livermore, $\mathrm{CA}$,

Container materials may undergo several modes of degradation in a repository environment, including: undesirable phase transformations due to lack of phase stability; atmospheric oxidation; general aqueous corrosion; pitting; crevice corrosion; intergranular stress corrosion cracking; and transgranular stress corrosion cracking. This paper is an analysis of data from the literature relevant to the pitting, crevice corrosion, and stress corrosion cracking of the three austenitic alloys which are candidate materials for waste containers.

Fernandez, J. A., T. E. Hinkebein, and J. B. Case, 1989. Selected Analyses to Evaluate the Effect of the Exploratory Shafts on Repository Performance at Yucca Mountain, SAND-85-0598, Sandia National Laboratories, Albuquerque, NM

This report presents a number of analyses to determine whether the construction of two exploratory shafts will significantly influence the long-term isolation capabilities of a high-level nuclear waste repository at Yucca Mountain. Both shafts are planned to be located predominantly in fractured, welded tuff within the unsaturated zone. The calculational effort, using analytical solutions, focuses primarily on the potential influence of the shaft liner and the zone of increased rock damage around the shaft [termed the modified permeability zone (MPZ)]. Two mechanisms are considered in determining whether the MPZ can significantly enhance radionuclide releases. These mechanisms include water flow entering the exploratory shafts from both realistic and improbable scenarios and airflow exiting the shaft as a result of convective and barometric forces. The influence of the liner on the performance of the repository is determined by evaluating the potential chemical interaction between ground water and the concrete liner and the subsequent potential for precipitates to deposit within the MPZ and the shaft fill. It is concluded from these calculations and the current knowledge of the hydrology of the unsaturated zone at Yucca Mountain that the presence of the shafts and the associated MPZ and shaft liner do not significantly impact the long-term isolation capability of the repository. 
Gertz, C. P., 1989. Journal of Nuclear Materials Management, 17(3): 10-13.

As mandated by Congress in the amended Nuclear Waste Policy Act, Yucca Mountain, Nevada is currently being studied by the DOE to determine if it is a suitable location for the nation's first geologic repository for disposal of high-level radioactive waste and spent nuclear fuel. While the site has attributes that suggest it may be suitable, DOE must spend the next five to seven years and up to $\$ 2$ billion to find out if the site would be able to isolate radioactive materials for 10,000 years. Site characterization studies are being conducted to determine the geologic, hydrologic and environmental characteristics of the Yucca Mountain site. The next five to seven years of study will determine if Yucca Mountain can meet regulations for waste isolation and qualify for a NRC license for repository construction and operation.

Grambow, B., and D. M. Strachan, 1988. A Comparison of the Performance of Nuclear Waste Glasses by Modeling, PNL-6698, Pacific Northwest Laboratory, Richland, WA.

Through a combination of data collection and computer modeling, the dissolution mechanism of nuclear waste glasses has been investigated and more clearly defined in this report. Data from static and dynamic leach tests are assembled, plotted, and successfully modeled and the kinetic parameters for these glasses are reported. The model can be used to calculate the effects of changes in the initial composition of the water contacting the glass and the effects of convective flow. Furthermore, glasses of different compositions can be readily compared using the model presented here.

Grenia, J., and L. Weyand, 1988. Impact Analysis on ESF Design for Calico Hills Penetration and Exploratory Drift and Tuff Main Extension to Limits of the Repository Block, DOE/NV/10322-35, Fenix and Scisson, Inc., Las Vegas, NV.

The study covers the impacts on project costs, schedule, human resources, and engineering designs caused by an increase in site characterization activity. Additional activities would include the penetration of the Calico Hills formation by an exploratory shaft (ES-1) and exploratory drifting to the Ghost Dance fault and/or drifting 10,000 feet southward from the ESF test complex area to the end of the proposed repository block.

Harris, R. N., and D. A. Ponce, 1988. High-Precision Gravity Network to Monitor Temporal Variations in Gravity Across Yucca Mountain, Nevada, USGS-OFR88-243, Geological Survey, Menlo Park, CA.

Repeatable high-precision gravity surveys provide a method of monitoring temporal variations in the gravity field. Fluctuations in the gravity field may indicate water table changes, crustal deformation, or precursors to volcanism and earthquakes. This report describes a high-precision gravity loop which has been established across Yucca Mountain. The purpose of this gravity loop is to monitor temporal variations in gravity across Yucca Mountain in an effort to interpret and predict the stability of the tectonic framework and changes in the subsurface density field. 
Holmes and Narver, Inc., 1988. Nevada Nuclear Waste Storage Investigations Atlas of Field Activities, Yucca Mountain, Nye County, Nevada, Volume II, DOE/NV/ 10576-T1-Vol. 2, Holmes and Narver, Inc., Las Vegas NV.

This document contains engineering drawings and support text for the Yucca Mountain Project Site Atlas.

Huber, N. K, 1988. Late Cenozoic Evolution of the Upper Amargosa River Drainage System, Southwestern Great Basin, Nevada and California, USGA-OFR-87-617, Geological Survey, Menlo Park, CA.

This report provides a historical description of the evolution of the Upper Amargosa River drainage system which was formed 11 million years ago. The gross drainage pattern has changed little in that time, implying a tectonic stability of the area.

Hunter, T. O., and F. W. Bingham, 1989. "Systems Performance Assessment for a Yucca Mountain Repository," from Waste Management '89, Tucson, AZ, February 26, 1989, SAND-89-0165C, Sandia National Laboratories, Albuquerque, NM.

The development of a geologic repository must include evaluations to determine whether the repository system can satisfy the regulatory requirements for postclosure waste isolation. The Yucca Mountain Project includes a performance assessment program that focuses on developing and applying methods to determine the isolation potential of the unsaturated tuff at Yucca Mountain. The methods must be based on an understanding of the fundamental concepts of fluid flow, radionuclide releases from the engineered-barrier system, and radionuclide transport in unsaturated, fractured rock. They must be capable of addressing both expected site conditions and unexpected potentially disruptive conditions. They must ultimately be efficient enough to accommodate numerous parameters and their associated uncertainties in the development of the statistical representations that are necessary to satisfy regulatory criteria. The existing methods are based on the current information about the site but will ultimately be supported by data to be obtained during site characterization.

Johnson, G. L., 1988. Thermal Performance of a Buried Nuclear Waste Storage Container Storing a Hybrid Mix of PWR and BWR Spent Fuel Rods, UCID-21414 Lawrence Livermore National Laboratory, CA.

The waste-container will provide the primary containment of radioactive waste and the spent fuel rod cladding will provide secondary containment. A series of transient conduction and radiation heat transfer analyses were run to determine for the first 1000 years of storage if the temperature of the tuff at the borehole wall ever falls below $97^{\circ} \mathrm{C}$ and whether the cladding of the stored spent fuel ever exceeds $350^{\circ} \mathrm{C}$. 
King, J. L., G. A. Frazier, and T. A. Grant, 1989. Assessment of Faulting and Seismic Hazards at Yucca Mountain, DOE/NV/10576-T3, Science Applications International Corporation, Las Vegas, NV.

Local faults at Yucca Mountain appear to be capable of moderate earthquakes at recurrence intervals of tens of thousands of years. The major issues identified for the preclosure phase are the location and seismic design of surface facilities for handling incoming waste. It is planned to address surface fault rupture by locating facilities where no discernible recent $(<100,000 \mathrm{yrs})$ faulting has occurred and to base the ground motion design on hypothetical earthquakes, postulated on nearby faults, that represent 10,000 yrs of average cumulative displacement.

Klavetter, E. A., R. R. Peters, and B. M. Schwartz, 1989. Experimental Plan for Investigating Water Movement Through Fractures: Yucca Mountain Project, SAND-840468, Sandia National Laboratories, Albuquerque, NM.

The manner in which water flows downward from the proposed Yucca Mountain geologic repository through the unsaturated zone to the water table can affect the transport of radionuclides. The travel time of water across a rock unit is considerably shorter if the flow is predominantly through fractures than if it is predominantly through the rock matrix. Current data and postulated physical models indicate that there is little or no significant flow through fractures in the unsaturated zone at Yucca Mountain. Fracture data are required to increase confidence in this conclusion and would be used qualitatively to increase understanding and quantitatively in modeling. The evaluation of water flow in fractures is also necessary for abnormal scenarios where significant fracture flow may occur because of future climatic conditions. An experimental system is described for the purpose of investigating the movement of water through fractures.

Neudecker, J. W. Jr., 1988. "Application of Rock Melting to Construction of Storage Holes for Nuclear Waste, ${ }^{n}$ from the Annual Meeting and of the Society of Mining Engineers, Inc., Las Vegas, NV, February 27, 1989, LA-UR-88-3961, Los Alamos National Laboratory, NM.

Rock melting technology can provide in-situ glass liners in nuclear waste package emplacement holes to reduce permeability and increase borehole stability. Reduction of permeability would reduce the time and probability of ground water contacting the waste packages. Increasing the stability of the storage boreholes would enhance the retrievability of the nuclear waste packages.

Nimick, F. B., L. E. Shepard, and T. E. Blejwas, 1988. Preliminary Evaluation of the Exploratory Shaft Representativeness for the Yucca Mountain Project, SAND-871685, Sandia National Laboratories, NM.

The representativeness of the data and information to be obtained in the exploratory shaft facility (ESF) relative to the site must be evaluated. This evaluation is based on evolving interpretations of limited data, much of which was obtained adjacent to, or outside the designated boundaries of the primary area. The representativeness of information scheduled to be obtained in the ESF has been evaluated for a number of technical disciplines including geology, mineralogy, rock mechanics, hydrology, waste package and repository design, and performance 
assessment. Results of this evaluation indicate that most data obtained in the ESF are expected to be representative of the primary area at Yucca Mountain.

Nimick, F. B., 1989. Thermal-Conductivity Data for Tuffs From the Unsaturated Zone at Yucca Mountain, Nevada, SAND-88-0624, Sandia National Laboratories, Albuquerque, NM.

This report is a compilation of thermal-conductivity data from 45 samples of tuffaceous rocks from Yucca Mountain, Nevada. Brief discussions of the experimental technique (transient-line-source) and experimental uncertainties also are included. The accuracy of the thermal-conductivity data cannot be assessed at present. The precision (repeatability) has been determined to be better than $+1-$ $2 \%$, in most cases.

Nitao, J. J., 1988. Numerical Modeling of the Thermal and Hydrological Environment Around a Nuclear Waste Package Using the Equivalent Continuum Approximation: Horizontal Emplacement, UCID-21444, Lawrence Livermore National Laboratory, CA.

In support of the investigations at Yucca Mountain computer simulations of the immediate thermal and hydrological environment around a nuclear waste package have been performed. Two dimensional computer simulations using a modified version of the TOUGH code were run for an idealized configuration derived from the COVE3 benchmarking effort consisting of a single spent fuel waste package with laterally periodic boundary conditions. The model domain extended downward to the water table and upward to the ground level. Fluid behavior in the rock was modeled using the equivalent continuum approximation. Simulations were made with surface water influx rates at the surface set to $0.1,0.5$, and $1.0 \mathrm{~mm} / \mathrm{yr}$. A significant amount of code modification and development was needed in order to develop the capability to perform these types of problems for the long time spans required.

Nitao, J. J., 1988. Simulations of the Near-Field Transport of Radionuclides by Liquid Diffusion at Yucca Mountain: Comparisons With and Without Emplacement Backfill, UCID-21466, Lawrence Livermore National Laboratory, CA.

The possible set of hydrologic conditions at Yucca Mountain includes the case where ground-water recharge fluxes are sufficiently low relative to molecular diffusion in the rock so that, in the region around the waste package, the dominant mode of aqueous transport of radionuclides is by diffusion. Although the rock at the proposed repository level is unsaturated, a sufficient amount of pore water could form a contiguous diffusion path from the waste form to the nearfield rock if the waste is postulated to be in contact with the rock or emplacement backfill due to failure of the container. Future simulations will have to include conditions where the effects of convective transport in the rock are important in aqueous transport. This report considers simplified simulations of one-dimensional transport of radionuclides in the rock due to liquid molecular diffusion in order to determine the effects of an emplacement backfill. The model is a simple onedimensional treatment of diffusion in a spherically symmetric geometry that takes into account the sorptive effects of the tuff and backfill through the use of $\mathrm{K}_{d}$ values. This geometry rather than a cylindrical one was chosen because it is 
conservative in predicting higher release rates. Radioactive decay is included, and only one species at a time is treated. The dissolution of the radionuclides is assumed to be solubility-limited.

Norris, A. E., 1989. "The Use of Chlorine Isotope Measurements to Trace Water Movements at Yucca Mountain," from FOCUS '89: Nuclear Waste Isolation in the Unsaturated Zone, September 18-21, 1989, LA-UR-89-2573, Los Alamos National Laboratory, NM.

The rates of water movements in the tuffs at Yucca Mountain are important for assessing the performance of a potential high-level nuclear waste repository. Measurements of chlorine-36 in tuff from the unsaturated zone and in water from the saturated zone can provide information about water movements over times of $10^{5}$ to $10^{6}$ years. The data derived from the analysis of cuttings from a dry-drilled hole at Yucca Mountain indicate the presence of a chlorine-36 background that must be taken into account. Similarly, the chlorine- 36 measured in water from the saturated zone requires additional work for correct interpretation.

Oak Ridge National Laboratory, 1988. Integrated Data Base for 1988: Spent Fuel and Radioactive Waste Inventories, Projections, and Characteristics, DOE/RW-0006, Rev. 4, Oak Ridge, TN.

The report presents current data on inventories and characteristics of commercial spent fuel and both commercial and US government-owned radioactive wastes through December 31, 1987. This data is based on the most reliable information available from government sources, the open literature, technical reports, and direct contacts. The current projections of future waste and spent fuel to be generated through the year 2020 and characteristics of these materials are also presented.

Olsson, W. A, 1988. Compliance and Strength of Artificial Joints in Topopah Spring Tuff: Yucca Mountain Project, SAND-88-0660, Sandia National Laboratories, Albuquerque, NM.

Capabilities for predicting the response of rock masses to thermomechanical loadings are being developed for the design of an repository at Yucca Mountain. An important ingredient in the computer codes being used is the constitutive description of the mechanical discontinuities (mostly joints, but also bedding planes and faults). This report summarizes preliminary laboratory experimental data on the compliance and the friction stress of artificial joints in Topopah Spring tuff in air-dry, room-temperature condition. Also, data for a laboratory-induced, clean tensile fracture are given. This report is primarily a catalogue of experiments and a surnmary of results.

Ramspott, L. D., 1988. "Assessment of Engineered Barrier System and Design of Waste Packages," from the American Nuclear Society Annual Meeting, San Diego, CA, June 12-16, 1988, UCRL-98029, Lawrence Livermore National Laboratory, CA.

The postclosure performance objectives for the Engineered Barrier System (EBS) require containment of the waste followed by controlled release. The EBS for a proposed repository in unsaturated tuff at Yucca Mountain is designed to meet 
these performance objectives with the major components being the waste form, container, air gap, and borehole liner. Assessment of postclosure performance of the EBS is based on allocating performance for various components toward meeting overall design objectives. Because of the unprecedented time periods considered, 1000 to 10,000 years, computer modeling is essential and will be used in conjunction with testing to assess whether the performance allocations are met.

Reimus, P. W., G. F. Repal, G. B. Mellinger, and L. R. Bunnell, 1988. West Valley Glass Production Qualification Durability Studies, FY 1987-1988: Effects of Composition, Redox State, Thermal History, and Groundwater, PNL-6723, Pacific Northwest Laboratories, Richland, WA.

The product qualification subtask of the West Valley Support Task at Pacific Northwest Laboratory provides support for the waste form qualification efforts at West Valley Nuclear Services Co. Testing is being conducted to determine waste form chemical durability in support of these efforts. The effects of composition, ferrous/ferric ratio (redox state), thermal history, and ground water are reported.

Reimus, P. W., A. M. Liebetrau, M. J. Apted, and D. W. Engel, 1988. "Performance Assessment for Spent Fuel Waste Packages at the Candidate Nevada Repository Site," from Spectrum 88: International Topical Meeting on Nuclear and Hazardous Waste Management, Pasco, WA, PNL-SA-15624, Pacific Northwest Laboratory, Richland, WA.

The Analytical Repository Source-Term (AREST) code is a preliminary performance assessment tool for evaluating waste package behavior in various geologic repository settings. The code is being enhanced to provide specific assessments of waste package performance in the hydrologically unsaturated welded tuff geology of Yucca Mountain.

Roy, D. M., and C. A. Langton, 1989. Studies of Ancient Concrete as Analogs of Cementitious Sealing Materials for a Repository in Tuff, LA-11527-MS, Los Alamos National Laboratory, NM.

The durability of ancient cementitious materials has been investigated to provide data applicable to determining the resistance to weathering of concrete materials for sealing a repository for storage of high-level radioactive waste. Ancient mortars, plasters, and concretes collected from Rome, Ostia, and Cosa dating to the third century $\mathrm{BC}$ show remarkable durability. The aggregates used in the mortars, plasters, and concretes included basic volcanic and pyroclastic rocks (including tuff), terra-cotta, carbonates, sands, and volcanic ash. The matrices of most of the ancient cementitious materials investigated have been characterized pozzolana/hydrated lime cements. The materials were characterized to elucidate aspects of the technology that produced them and their response to the environmental exposure throughout their centuries of existence. Their remarkable properties are the result of a combination of chemical, mineralogical, and microstructural factors. Their durability was found to be affected by the matrix mineralogy, particle size, and porosity; aggregate type, grading and proportioning; and the methodology of placement. 
Scheetz, B. E., and D. M. Roy, 1989. Preliminary Survey of the Stability of Silica-Rich Cementitious Mortars 82-22 and 84-12 with Tuff, LA-11222-MS, Los Alamos National Laboratories, NM.

Two cementitious formulations were prepared that contained mixtures of silicaadjusted cementitious binder and tuff of the Topopah Spring member. Both formulations were developed to possess a bulk chemical composition that approached the bulk silica-to-alumina ratio of the tuff of the Topopah Spring Member. The two formulations represent examples of an expansive and a nonexpansive cementitious sealing material. The expansive grout relies on the formation of ettringite to generate the expansive forces. Phase characterization of the reaction products for the expansive grout revealed that the expansive agent, ettringite, was not stable above about $100^{\circ} \mathrm{C}$. Tobermorite was observed at all temperatures, even at $300^{\circ} \mathrm{C}$, well above its expected stability limit. The incorporation of aluminum into the tobermorite structure is postulated as contributing to the enhanced thermal stability. In the longer experiments, at 200 and $300^{\circ} \mathrm{C}$, the aluminum-tobermorite partially reacted with excess $\mathrm{SiO}_{2}$ to form truscottite, another calcium silicate hydrate.

Science Applications International Corporation, 1988. Yucca Mountain Project Site Atlas: Volume 1, DOE/NV/10516-T1, Las Vegas, NV.

The Yucca Mountain Project Site Atlas is a reference document of field activities which have been, or are being, conducted to support investigations of Yucca Mountain. The investigations will yield geologic, geophysical, geochemical, geomechanical, hydrologic, volcanic, seismic, and environmental data necessary to characterize Yucca Mountain and its regional setting.

Sheppard, R. A., A. J. Gude, and J. J. Fitzpatrick, 1988. Distribution, Characterization, and Genesis of Mordenite in Miocene Silicic Tufts at Yucca Mountain, Nve County, Nevada, USGS-BULL-1777, U.S. Geological Survey, Denver, CO.

Yucca Mountain is being investigated as a possible deep repository for high-level radioactive wastes. A sequence, as much as about $\mathbf{3 0 0 0}$ meters thick, of Miocene silicic ash-flow tuffs, bedded tuffs, lavas, and flow breccias was derived chiefly from the Timber Mountain-Oasis Valley caldera complex. Previous studies by others of core from several drill holes have shown that much of the original vitric material of the volcanic and volcaniclastic rocks was altered during diagenesis to clay minerals, silica minerals, zeolites, and feldspars. Unaltered glass still persists in the upper part of the sequence, but zones characterized by clinoptilolite and mordenite, analcime, and albite follow in succession with depth.

Siegal, M. D., S. L. Phillips, J. O. Leckie, and W. P. Kelly, 1988. "Development of a Methodology of Geochemical Sensitivity Analysis for Performance Assessment," from Geostatistical Methods for 'Transport Modeling, San Francisco, CA, September 1988, SAND-87-1133C, Sandia National Laboratories, Albuquerque, NM.

The objective of this paper is the formulation of criteria for simplification of radionuclide transport models used in performance assessments. The complementary roles played by simple transport models designed to bound the radionuclide discharge over wide ranges of physiochemical conditions and detailed 
geochemical models that provide a structured method to obtain reliable information about solute/rock/water interactions. Sensitivity and uncertainty analysis techniques used to assess the significance of errors in both data and models are also addressed.

Simonson, S. A, 1988. Modeling of Radiation Effects on Nuclear Waste Package Materials, DOE/OR/00033-T415, Massachusetts Institute of Technology, Cambridge, MA

A methodology is developed for the assessment of radiation effects on nuclear waste package materials. The methodology is used to predict chemically induced changes in the ground water surrounding nuclear waste packages in a repository in tuff. The methodology embodies a physical model of the effects of radiation on aqueous solutions. Coupled to the physical model is a method for analyzing the complex nature of the physical model using adjoint sensitivity analysis. The sensitivity aid in both the physical understanding of the processes involved as well as in eliminating portions of the model that have no bearing on the desired results. A computer implementation of the methodology is provided.

Sinnok, S., and T. Lin, 1988. "Preliminary Estimates of Ground-water Travel Time at Yucca Mountain," from the American Nuclear Society meeting, San Diego, CA, December 17, 1988, SAND-88-0027C, Sandia National Laboratories, Albuquerque, NM.

This report presents the assumptions, methods, and results of a probabilistic approach to the calculation of ground-water travel times to the water table below Yucca Mountain. Because flow in the portion of the unsaturated zone below the proposed repository is probably nearly steady state and vertical, the flow was assumed to be driven vertically downward solely by elevation head along the direction of gravity. On the basis of this assumption, a reasonable approximation of the velocity of water through the unsaturated zone was obtained by dividing the flux by an effective porosity.

Smith, H. D., 1988. Initial Report on Stress-Corrosion-Cracking Experiments Using Zircoloy-Spent Fuel Cladding C-Rings, WHC-EP-0096, Westinghouse Hanford Company, Richland, WA

C-ring stress corrosion cracking scoping experiments are being conducted as a first step in evaluating the potential for stress corrosion cracking of spent fuel cladding in a potential tuff repository environment. The objective is to assess the approximate behavior so that more precise pressurized tube testing can be performed over an appropriate range of stress conditions.

Smith, H. D., 1988. Electrochemical Corrosion-Scoping Experiments: An Evaluation of the Results, WHC-EP-0065, Westinghouse Hanford Company, Richland, WA.

Prior to emplacement in a nuclear waste repository, each waste form must be well characterized with respect to its behavior in the environments expected to be present in the repository. This scoping study was designed to obtain a qualitative idea of 
how spent fuel cladding would respond to a hot water environment that could develop in a tuff repository at a time when temperatures have cooled to approximately $95^{\circ} \mathrm{C}$ and hot liquid water has infiltrated the repository horizon.

Subramanian, C. V., and A. H. Hadjian, 1989. "Cost-Benefit Assessment Methodology for Seismic Design of High-Level Waste Repository Facilities," from the International Conference on Structural Mechanics in Reactor Technolog, Anaheim, CA, August 14-18, 1989, SAND-88-1931C, Sandia National Laboratories, Livermore, CA.

This paper summarizes a methodology for performing a cost-benefit assessment of the seismic design of the surface facilities associated with the prospective highlevel radioactive waste repository at Yucca Mountain. The methodology described will develop the costs and benefits of varying design levels for vibratory ground motion and surface fault displacements for structures, components, and equipment in the repository facilities.

Thomas, K. W., 1988. Research and Development Related to the Nevada Nuclear Waste Storage Investigations: Progress Report, October 1 - December 31, 1984, LA-11443PR, Los Alamos National Laboratory, NM.

This report summarizes some of the technical contributions by the Los Alamos National Laboratory to the Nevada Nuclear Waste Storage Investigations Project from October 1 through December 31, 1984. The report is not a detailed technical document but indicates the status of the investigations performed at Los Alamos National Laboratory.

Tillerson, J. R., J. A. Fernandez, and T. E. Hinkebein, 1989. "Uncertainties in Sealing a Nuclear Waste Repository in Partially Saturated Tuff," from the Joint NEA/ CEC Workshop on Sealing of Radioactive Waste Repositories, Braunschweig, Germany, F.R., May 22-25, 1989, SAND-89-1285C, Sandia National Laboratories, Albuquerque, NM.

Design and performance of components for sealing shafts, ramps, drifts, and exploratory boreholes depends on specific features of both the repository design and the site. Of particular importance is the hydrologic environment in the unsaturated zone, including the role of fracture flow. Repository design features important to sealing of a repository include the size and location of shaft and ramp accesses, excavation methods, and the underground layout features such as grade (drainage direction) and location relative to geologic structure. Uncertainties about seal components relate to the postclosure environment for the seals, the emplacement methods, the material properties, and the potential performance of the components. This paper describes an approach to reduce uncertainties and to increase confidence in seal performance. The approach includes gathering extensive site characterization data, establishing conservative design requirements, testing seal components in laboratory and field environments, and refining designs of both the seals and the repository before seals are installed. 
West, K. A, 1988. Nevada Nuclear Waste Storage Investigations: Exploratory Shaft Facility Fluids and Materials Evaluation, LA-11398-MS, Los Alamos National Laboratory, Los Alamos, NM.

To properly characterize Yucca Mountain an underground test facility will be constructed to conduct in situ site characterization tests. The candidate repository horizon at Yucca Mountain, however, could potentially be compromised by fluids and materials used in the site characterization tests. This analysis evaluates the kinds of fluids and materials that will be used and their potential impacts on the site and identifies fluids and materials, if any, that should be prohibited from, or controlled in, the underground.

Yabusaki, S. B., C. R. Cole, O. J. Holford, A. M. Monti, and S. K. Gupta, 1988. HYDROCOIN (Hydrologic Code Intercomparison) Level I: Benchmarking and Verification Test Results with CFEST (Coupled Fluid, Energy, and Solute Transport) Code, PNL/SRP-6681, Pacific Northwest Laboratory, Richland, WA.

DOE participated in the International Hydrologic Code Intercomparison (HYDROCOIN) project for the purpose of improving knowledge about the influence of various strategies for ground-water flow modeling. The project consisted of three levels of effort: (1) Level 1 was concerned with verifying the numerical accuracy of the code, (2) Level 2 was involved with validation of models using field experiments, and (3) Level 3 was concerned with sensitivity and uncertainty analysis. This report presents the Level 1 results furnished by the project teams.

Zimmerman, R. M., R. A. Bellman, K. L. Mann, D. P. Zerga, N. Fowler, and J. R. Johnson, 1988. G-Tunnel Welded Tuff Mining Experiment Evaluations, SAND-87-1433, Sandia National Laboratories, Albuquerque, NM.

Designers and analysts of radioactive waste repositories must be able to predict the mechanical behavior of the host rock. A mine-by in welded tuff in G-Tunnel on the Nevada Test Site was conducted so that predictive-type information could be obtained regarding the response of the rock to a drill and blast excavation process, where smooth blasting techniques were used. This report describes the results of the mining processes and presents and discusses the rock mass responses to the mining and ground support activities.

Zimmerman, R. M., K. L. Mann, and D. J. Dodds, 1989. "Results of Pressurized-Slot Measurements in the G-Tunnel Underground Facility," from the US Symposium on Rock Mechanics, Morgantown, WV, June 19-22, 1989, SAND-88-3410C, Sandia National Laboratories, Albuquerque, NM.

Rock mechanics field experiments have been conducted in G-Tunnel at the Nevada Test Site, where tuffs similar to those at Yucca Mountain are found. A feature of the rock mechanics program has been the development of a testing program for cutting thin slots in a jointed welded tuff and utilizing flatjacks for pressurizing these thin-slots on a relatively, large scale. Objectives in the pressurized slot testing in G-Tunnel have been to apply and possibly improve methods for (1) utilizing the flatjack cancellation method for measuring stresses normal to the slot, and (2) measuring the modulus of deformation of the jointed rock 
surrounding the slot. This paper discusses the results of field measurements in and around a single slot and evaluates potential applications and limitations.

Zumberge, M. A. R. N. Harris, H. W. Oliver, G. S. Sasagana, and D. A. Ponce, 1988. Preliminary Results of Absolute and High Precision Gravity Measurements at the Nevada Test Site and Vicinity, Nevada, USGS-OFR-88-242, Geological Survey, Menlo Park, CA.

This report presents the preliminary results of absolute gravity measurements made at four sites in southern Nevada using the absolute gravity free fall apparatus. Three of the sites are located on the Nevada Test Site at Mercury, Yucca Pass, and in northern Jackass Flats. The fourth site is at the Kyle Canyon ranger station near Charleston Park. 